\title{
ELENA ZVARÍKOVÁ PAPPOVÁ. FEMME FATALE SLOVENSKÉHO HERECTVA
}

\author{
KAROL MIŠOVIC \\ Ústav divadelnej a filmovej vedy Centra vied o umení Slovenskej akadémie vied, Bratislava
}

\begin{abstract}
Abstrakt: Elena Zvaríková Pappová (1935 - 1974) patrila medzi najosobitejšie zjavy slovenského herectva druhej polovice 20. storočia, no jej umelecký profil nebol dodnes teatrologicky komplexne spracovaný. Herečkine najzaujímavejšie roky sa viažu na angažmán v Divadle Slovenského národného povstania Martin (1954 - 1968). Tu spočiatku stvárňovala epizódne postavičky a žánrové figúrky, od konca pätdesiatych rokov sa však postupne stávala protagonistkou súboru. Dokázala si poradit’ s javiskovou štylizáciou, ale najlepšie sa cítila v civilnej divadelnej poetike. V nej nachádzala vhodný priestor na vierohodné stvárnenie vnútorných konfliktov a dráždivej dramatickosti postáv. Charakteristické boli pre ňu roly žien plebejských, dominantných a nespútaných. Jej korpulentnejší výzor a schopnost’ humorného nadhladu režiséri pravidelne využívali v komediálnom repertoári, no stala sa aj vyhl’adávanou predstavitelkou osudových žien , ktoré prinášali na javisko sexuálnu dráždivost’ i prudkú živočíšnost'. Následný prechod do činohry Slovenského národného divadla v roku 1969 pre ňu znamenal prudký pokles hereckých príležitostí.
\end{abstract}

Kl'účové slová: Elena Zvaríková Pappová, herectvo, Divadlo Slovenského národného povstania Martin, Slovenské národné divadlo, šest’desiate roky 20. storočia

,.... predstavitel'ka moderného analytického herectva (...), presvedčivost’ a psychologická pravdivost’ [jej výkonov] sa spájali s nepatetickým tragizmom a postihnutím osobnosti v celej zložitosti vzt’ahov a motivácií. " 1 Tak autor hesla v Encyklopédii dramatických umení Slovenska stručne, avšak výstižne charakterizoval umenie Eleny Zvaríkovej Pappovej (5. 5. 1935 - 17. 8. 1974)² , herečky, ktorá si napriek krátkemu životu dokázala vybojovat' popredné miesto v histórii slovenského divadelníctva. Pamätníci pripomínajú najmä kreácie vášnivých femmes fatales, ktoré sa stali jej určujúcim hereckým odborom. Podl'a kritika Stanislava Vrbku, herečka prinášala na javisko sexappeal, erotiku i sex. Robila to „bez toho, aby sa o to nejako zvlášt usilovala: tajomne zastretým hlasom, unylým, upretým, vyzývavým pohl’adom a pohybom zaliečavej mačky, z ktorej sa často stávala útočná tigrica“. ${ }^{3}$ Preto pravidelne stvárňovala „ženy, ktoré sa zmietajú v súkolí všednej, banálnej každodennosti, často ženy z periférie či podsvetia“" Ženy živelné a duševne disharmonické, vždy (márne) túžiace po upokojení svojich vnútorných nepokojov.

\footnotetext{
${ }^{1}$ kol. Encyklopédia dramatických umení Slovenska II : M - Ž. Bratislava : Veda, 1990, s. 584.

${ }^{2}$ Elena Pappová (vo vlastnom životopise si uvádzala meno Helena) sa v roku 1957 vydala za lekára Emila Zvaríka (brata herca SND Františka Zvaríka) a začala používat meno Elena Zvaríková Pappová. V bulletinoch, filmových titulkoch, recenziách či rôznych tlačovinách môžeme nájst’ niekol'ko variácií prepisov jej mena. V štúdii používame formu Elena Pappová a pri analýze jej kariéry po roku 1957 Elena Zvaríková Pappová.

${ }^{3}$ VRBKA, S. Elena Zvaríková - od mladosti pani herečka. In Listy SND, propagačný dvojmesačník, 1989 -1990 , č. 5 , s. 8.

${ }^{4}$ R. Odišla hrdinka Čechovových hier. In Film a divadlo, 1974, roč. 18 , č. 20 , s. 15.
} 


\section{Z hádzanárky herečka}

Povojnové slovenské divadelníctvo sa rýchlo vyvíjalo nielen v zmysle kvality, ale aj kvantity. Od druhej polovice štyridsiatych rokov postupne sledujeme rozširovanie divadelnej siete po celom území republiky. Vzniká bratislavská Nová scéna Národného divadla, Ukrajinské národné divadlo v Prešove, Stredoslovenské divadlo vo Zvolene, Divadlo pracujúcich v Považskej Bystrici, Nitrianske krajové divadlo, zájazdové Dedinské divadlo a i. Najväčší rozmach v zakladaní divadelných inštitúcií nastal najmä v období po februári 1948, ked’ komunistická strana získala v krajine absolútnu moc a kultúrni ideológovia považovali živé javiskové umenie za výborný prostriedok na šírenie politickej osvety.

Na Slovensku sa ale vyskytol problém s personálnou obsadenostou čerstvých stánkov Tálie. Kým v Čechách už existovala Akadémia múzických umení a jej činnosti produktívne predchádzalo pražské konzervatórium, na Slovensku nemal kto dodávat' nové posily do divadiel so stálym ansámblom. Vysoká škola múzických umení vznikla v roku 1949 a prví diplomovaní absolventi hereckého štúdia z nej vyšli až o štyri roky neskôr. To už bolo pre preexponovanú mapu oblastných divadiel neskoro. Preto Státne konzervatórium, ktoré bolo do vzniku VŠMU jedinou slovenskou školou zameranou na výučbu dramatického umenia, reagovalo na tento dopyt vznikom Odborného divadelného kurzu (ODK). Štúdium tam netrvalo bežné štyri roky, mladí herci získali absolutórium na úrovni konzervatória už po dvoch ročníkoch. A okamžite po ukončení školy po nich siahali divadlá, ktoré sa snažili doplnit’ svoje ansámble o profesionálnych umelcov, ked’že dovtedy museli čerpat’ najmä z radov agilných ochotníkov.

Zriadenie ODK bolo síce dočasným, ale v akútnej situácii pragmatickým krokom. I ked’ by sa mohlo zdat', že skrátené štúdium bolo len rýchlokurzom, z jeho troch turnusov v rozpätí rokov 1950 - 1954 vyšli umelci, ktorí nasledujúce desat'ročia patrili ku klúčovým osobnostiam našich kultúrnych dejín: Zdena Gruberová, Eva Krížiková, Carmen Farkašová (neskôr známa ako Hana Hegerová), Žofia Martišová, Miloš Pietor, Leopold Haverl, Vlado Müller, Emília Došeková či Elena Pappová.

Elena Pappová mala ako rodená Bratislavčanka už od detstva možnost’ sledovat’ divadelné dianie v Národnom divadle ${ }^{5}$ aj na Novej scéne ND, ale spočiatku sa zdalo, že jej múzické umenie ostane vzdialené. Ako mladé dievča hrávala hádzanú za Kovosmalt Petržalka, no nakoniec vzt’ah k divadlu prekonal všetky ostatné záujmy a prihlásila sa na ODK. Po úspešnom zložení skúšok nastúpila do ročníka, ktorý pedagogicky viedli poprední bratislavskí herci Ondrej Jariabek a Milada Želenská. Charakterová interpretka Milada Želenská, pokračovatel'ka dlhovekej rodinnej divadelníckej tradície, bola pamätníčkou a hereckou účastníčkou emblémových inscenácií moderných režisérov prvých rokov profesionálneho slovenského divadla - Viktora Šulca, Ferdinanda Hoffmanna a Jána Jamnického, aj protagonistkou javiskových diel povojnovej generácie - Magdy Husákovej Lokvencovej či Františka Kudláča. V Pappovej hereckom profile môžeme lahko odhalit priame ozveny jej pedagogičky. Obe herečky mali totiž mnohé spoločné črty - fyziognómiu plnokrvnej ženy, vrodené predpoklady pre úlohy domín aktívne sa zapájajúcich do ostrých konfliktov, aj zmy-

${ }^{5}$ V rokoch 1942 - 1958 používalo Slovenské národné divadlo názov Národné divadlo. 
sel pre bytosti vnútorné deštruované, ale navonok si uchovávajúce esprit nedotknutel’nosti pred okolitými vplyvmi.

Želenská síce Pappovej približovala základy divadelného remesla, ale iba v školských učebniach. V praxi spoznala zákonitosti i nutnosti hereckého povolania vd’aka hostovaniu v inscenáciách režisérov ND Jozefa Budského a Ivana Licharda. Samozrejme, vo väčšine prípadov išlo iba o výplň davových scén vo výpravných inscenáciách, dominujúcich v tej dobe repertoárom všetkých divadiel. Režiséri však museli v mladej adeptke vycítił závan výrazného talentu, lebo jej obaja ponúkli možnost' nielen sa na javisku objavit’ v početnom dave štatistov, ale aj prehovorit’ svoje prvé repliky. Ivan Lichard ju obsadil do epizódnej úlohy Dory, žnice v Palárikovej obrodeneckej veselohre Dobrodružstvo pri obžinkoch (4. 11. 1953) a v réžii Jozefa Budského stvárnila stredne vel'kú rolu L’udmily Vavríkovej v Karvašovej socialistickej agitke Srdce plné radosti (30. 1. 1954). Obe dievčenské postavy sú v celkovom pohl'ade na Pappovej tvorbu síce zanedbatel’né, no pre mladú študentku učiacu sa samostatnej javiskovej existencii boli nezastupitel'né. Nehovoriac o tom, že prvé skúsenosti zbierala v spoločnosti vyspelých činoherných protagonistov prvej scény Ctibora Filčíka, Gustáva Valacha, Karola Machatu, Márie Bancíkovej, Márie Prechovskej či Bety Poničanovej. Z ich zrelého hereckého štýlu mohla čerpat’ inšpirácie pre prácu s javiskovou rečou, vnútornú aj vonkajškovú charakterizáciu postáv i realistickú prirodzenost̉ ich javiskového výrazu.

Ked' do výpočtu prvých herečkiných rol pridáme dve nasledujúce úlohy v Hollého komédii Kubo (4. 6. 1954), ktorú poslucháči ODK naštudovali v réžii Ondreja Jariabka ako svoju absolventskú inscenáciu, vznikne dojem, že Pappová bola vhodnou adeptkou pre postavy z dedinského prostredia. Všetky dovtedajšie roly totiž pochádzali z vidieka, či už súčasného alebo historického. Mohlo sa teda zdat', že bude logicky nasledovat’ rad starších kolegýň, herečiek naturelom zrastených s rurálnostou slovenského vidieka, Ol'gu Borodáčovú Országhovú, Betu Poničanovú a Evu Kristinovú. No opak bol pravdou: Pappová bola už v zárodku kariéry herečkou Želenskej typu - predstavitel'kou žien 20. storočia, živelne rebelujúcich hrdiniek, mondénnych a nad prízemnost' bežného sveta povznesených dám, ale i zúfalých všedných existencií, ktoré v okolitom chaose márne hladajú aspoň zárodky duševnej stability. Pappová bola zároveň predstavitel'kou moderného výrazu, interpretkou nekompromisne odhal'ujúcou emočnú pravdivost’ a intelektuálne horizonty súčasných žien. Aj ked' letmý pohl'ad na jej prvé úlohy akoby negoval tento fakt, herečke už od začiatku profesionálnej dráhy vyhovovali postavy, v ktorých mohla cez nenútený až nedivadelne pôsobiaci prejav hovorit’ pravdy o dnešnom svete, dnešných l'ud’och a pre dnešných divákov.

Kusé informácie o inscenácii Kuba nedávajú šancu na bližšiu analýzu Pappovej výkonov v krížovej alternácii postav cigánky Dory a dedinskej fanfarónky Anny Bečelovej. Môžeme ostat' len pri predpokladoch o jej hereckom nadhl'ade, s mierou využitom temperamente a zmysle pre komickú pointu, ktorými tvarovala svoje neskoršie výkony v martinskom divadle. No jedno je isté, herecky musela zaujat'. Inak by čerstvej absolventke ODK neprišla ponuka angažmánu z najprestížnejšieho slovenského regionálneho divadla - z Armádneho divadla Martin, kam nastúpila 27. 7. 1954. 


\section{Ne/tuctová tvár}

Martinské Armádne divadlo malo v čase herečkinho nástupu za sebou prvú dekádu profesionálnej existencie, ale napriek jeho mladosti nemôžeme hovorit’ o nezrelosti. Martinská scéna aj po profesionalizácii zotrvala na pozícii klúčového divadelného centra, ktoré si napriek mnohým provizóriám a personálnym nevýhodám (vel'ký počet premiér, fluktuácia v súbore, povinná zájazdová činnost’ po širokom regióne) udržiavalo nadpriemernú umeleckú úroveň. Mladá absolventka však vstúpila na jeho javisko v dobe, ked' začalo mierne ustupovat' z vydobytých kvalitatívnych pozícií. Súbor a tým aj inscenácie trpeli častými odchodmi mladých členov z ansámblu i obmenami režisérskeho zboru. Napríklad tesne pred Pappovej príchodom opustili Armádne divadlo jej dve o ročník staršie spolužiačky z ODK Eva Krížiková a Zdena

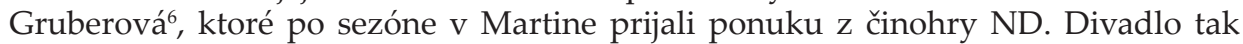
urýchlene potrebovalo doplnit' stav mladých hercov.

Dalo by sa predpokladat', že Pappová sa okamžite po nástupe dostala k vel'kým dramatickým úlohám. No nebolo to tak. I ked' martinské divadlo zrejme privítalo príchod mladej posily, ženská čast’ ansámblu bola plná len o pár rokov starších umelkýň, v dobe jej začiatkov už zrelých charakterových herečiek. Pappová bola zatial' iba učnicou, ktorá musela prvé roky viac vyčkávat’ v tieni kolegýň než stvárňovat' vel'ké roly vo svetle reflektorov. Konkurencia bola značná: Katarína Hrobárová Vrzalová, Eliška Nosálová, Helena Sudická, Eva Rysová, Hilda Michalíková, Marica Bálintová i česká herečka s precíznou slovenčinou Květa Fialová. Popri tom bola výraznou nevýhodou a logickou príčinou slabšieho využitia ženskej časti ansámblu povinná dramaturgická orientácia divadla na armádne témy. V hrách o povstaniach, vojenských bojoch a politických sporoch pridel'ovali autori ženským postavám menší priestor. Preto muselo umelecké vedenie takticky dbat’ na rovnomerné rozloženie síl v súbore.

Chod divadla zároveň tažko zasiahli odchody určujúcich režisérov prvej polovice pät’desiatych rokov, ktorí dokázali aj v časoch najtvrdších tlakov socialistického realizmu udržat’ divadlo v nadpriemernej umeleckej kondícii. Otto Haas v roku 1956 prijal angažmán v Českých Budejoviciach, Martin Hollý st. v roku 1958 odišiel konsolidovat’ umeleckú úroveň Divadla Petra Jilemnického v Žiline, v tom istom roku odchádza i Dezider Janda do zvolenského divadla, kam ho o rok neskôr nasleduje Juraj Hal’ama. Pappová síce ešte zachytila posledné ozveny kvarteta silných režijných osobností, ale jej kvality u nich nenašli okamžitú rezonanciu. Herečkin talent musel čakat’ na postupné odhal'ovanie a najmä prehlbovanie. Hrávala síce pravidelne a vel’a, ale väčšinou išlo o menšie, pre význam javiskového celku niekedy až zanedbatel'né úlohy.

Jej nástupnou inscenáciou bola Bukovčanova veselohra Surovô drevo (2. 10. 1954). Nestvárnila v nej hlavnú hrdinku, amatérsku speváčku Žofku, ale jednu z tria jej kamarátok Betu - energickú, ale dramatickým významom bezpríznakovú dievčinu. Práve séria podobných, pre herecké rozvíjanie sa nevd’ačných a dramaturgicky nevýbojných úloh začala lemovat’ Pappovej kariéru. Až do prelomu desatročí bola predstavitel'kou malých dievčenských rol, v ktorých nemala šancu zahrat’ viac, ako

\footnotetext{
${ }^{6}$ Zaujímavost’ou je, že Zdena Gruberová po nástupe do ND doštudovala práve Pappovej úlohy v Dobrodružstve pri obžinkoch a v Srdci plnom radosti.
} 
jej určovalo niekol'ko replík. Vo väčšine prípadov išlo o postavy životaschopných slečien, slabomysel’ných naiviek, sentimentálnych preciózok, neštastne zamilovaných krások či milo komických figúrok. Ale k podstatných úlohám, v ktorých by mohla dokázat’ prirodzený príklon k postavám výsostne dramatickým a po každej stránke komplikovaným, sa nedostávala. Nezanedbatel’ným aspektom bola aj skutočnost', že Pappová pôsobila popri kolegyniach príliš tuctovým dojmom. Až o pár rokov neskôr dospela k výzoru zrelej, sebavedomej a fyziognómiou neprehliadnutel'nej ženy.

V prvej pätročnici angažmánu bola predstavitel'kou všeobecného typu dievčat, nositel'kou skôr nevýraznej krásy a na prvý pohlad introvertného naturelu. Dobové fotografie ju približujú ako mladú ženu s bujnými, mierne vlnitými tmavými vlasmi, oválnou tvárou, vel'kými očami zasadenými nad okrúhlymi lícami a s medzierkou v mierne vysunutej brade. Nemala ideálne miery, nebola síce korpulentná, ale zodpovedala typu „krv a mlieko“. Jej herecký naturel sa automaticky bránil klasicisticky strohému gestu, patetickému tónu, aj ilustratívnym, realistickým prostriedkom. I preto sa Pappovej vyhýbali postavy z diel klasikov. Úlohy z hier Shakespeara či Goldoniho boli skôr náhodnými stretnutiami. Jej kariére dominovali roly žien 20. storočia, a to v celej jeho dovtedajšej dížke: od Čechova, Gorkého či Shawa až po úlohy z diel autorov diagnostikujúcich polaritu prebiehajúcej súčasnosti - Sartra, Dürrenmatta, Casonu, Arbuzova a i.

Toto všetko však môžeme konštatovat’ o Pappovej až na prelome pätdesiatych a šest'desiatych rokov, ked' vyniklo jej umenie skratky, jemnej nuansovanej kresby duševných polemík a nedeklamačného hereckého slohu. Na úsvite kariéry ju síce považovali za herečku spol’ahlivú, nepodliezajúcu kvalitatívnu latku martinského ansámblu, ale predsa iba rodiacu sa. Na malých dramatických plochách totiž nemala príležitost' preukázat’ dispozície pre prácu s podtextom, intelektuálny prienik do podstaty úloh či schopnost’ akoby nebadaných, no charakterizačne dôsledných a významotvorných valérov. Neskôr nadmieru oceňované atribúty jej hereckej osobnosti - neustávajúca vnútorná tenzia, napätím pulzujúce zámlky, bystré oči schopné reflexívne konkretizovat’ nastolenú vztahovú štruktúru - ostávali režisérmi zatial prehliadané. Napriek tomu sa snažila dodat' každej postave či postavičke prvky jedinečnosti, hereckej svojbytnosti a naliehavosti výpovede.

To postupne prinášalo prvé úspechy. Svedčí o tom napríklad stručná kritická reflexia (pravdepodobne prvá na martinskom pôsobisku) jej výkonu v inscenácii drámy Julija Petroviča Čepurina Jarné vody (30. 12. 1954), v ktorej v krížovej alternácii s Gitou Mazalovou stvárnila roly Zoje a Gale: „Úprimnejšia a milšia bola Gal’a v podaní Pappovej. Presvedčila nás svojou milou dievčenskou láskou a po smrti svojho Silkina vedela svojím precítením strhnút’ obecenstvo. ${ }^{\prime 7}$ Hodnotenie síce kusé a pre dnešnú rekonštrukciu výkonu primálo obsažné, ale vyplýva z neho, že Pappovej herectvo postupne dozrievalo na náročnejšie úlohy. Tie však stále neprichádzali. V kontexte situácie po roku 1960, ked’ sa z herečky každodenného typu stala protagonistka súboru, znie až paradoxne, že v prvom období kariéry bola len Tretou dámou v Popovom Port Arturovi (5. 12. 1954), neštastne zamilovanou kurtizánou Biancou v Shakespearovom Othellovi (9. 4. 1955), vrtošivou sekretárkou Vierkou v Stodolovej satire

\footnotetext{
${ }^{7}$ MICHAELLI, D. Čepurinove „Jarné vody“ v Armádnom divadle. Bližšie neidentifikovaný výstrižok článku sa nachádza v inscenačnej obálke Julij Petrovič Čepurin : Jarné vody (premiéra 30. 12. 1954) v Zbierke inscenácií Divadelného ústavu v Bratislave.
} 


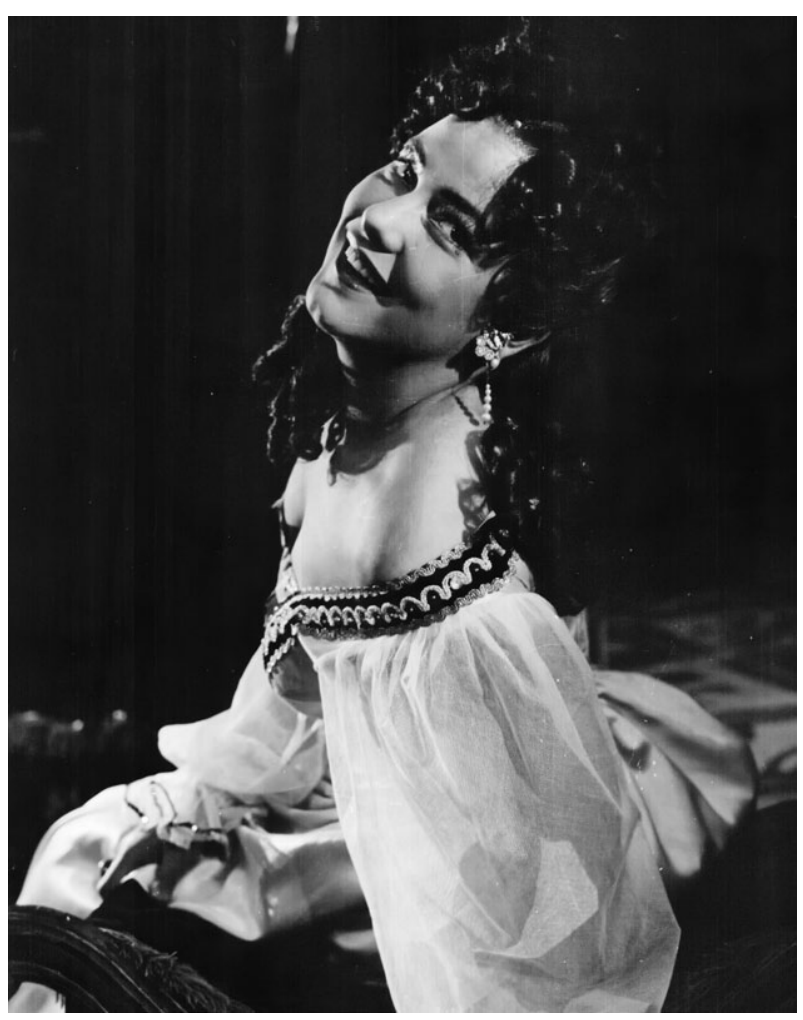

Ben Jonson: Volpone. Elena Pappová (Canina). Armádne divadlo Martin, premiéra 31. 3. 1957. Réžia Martin Hollý st. Foto archív SKD Martin.

Jožko Púčik a jeho kariéra (28. 5. 1955), biedermeirovsky krásnou, ale dramaticky nevýbojnou Evičkou v Palárikovom Inkognite (26. 5. 1956), pyšnou princeznou Zulikou v Tylovom Strakonickom gajdošovi (13. 4. 1958), jednou z čarodejníc v Shakespearovom Macbethovi (25. 3. 1959) či ideologickou tézovitostou zviazanou Katkou v Karvašovej Polnočnej omši (30. 5. 1959). Herečku jednoznačne obchádzali roly širšieho charakterového rozsahu alebo aspoň inscenácie, ktoré by sa výraznejšie zapísali do histórie martinského divadla. Nebola totiž súčastou Schillerových Úkladov a lásky (9. 10. 1954), Višnevského Optimistickej tragédie (19. 7. 1956) ani Sofoklovej Antigony (22. 12. 1956), teda profilových čísiel repertoáru tej doby.

Problém spočíval v tom, že herecký štýl Eleny Pappovej sa vymykal dobovým konvenciám pätdesiatych rokov minulého storočia. Nebola herečkou deklamátorkou, herečkou so zvučným a melodickým hlasom, herečkou deskriptívne pretavujúcou Stanislavského princípy do javiskovej praxe. Pappovej herecký sloh už od mladosti smeroval k civilnej palete výrazového registra. Jej vonkajškové prostriedky boli neteatrálne, pevne zviazané s bohatou akceleráciou duševných pohnútok, ktoré nevychádzali na povrch $\mathrm{v}$ afektovaných blokoch. Vo výraze sa bránila chladnej monumentalite, falošnému pátosu i deskriptívnemu naturalizmu. Napriek fyziognomickým predpokladom bola opakom zasnívaných a sentimentálnych slečien. Už od počiatku smerovala k nekompromisne psychoanalytickým prienikom do komplikovanej ženskej psychiky. K tomu jej však tézovité roličky socialistického repertoáru 
bez osobitejšej charakterovej či aspoň typovej špecifickosti nedokázali poslúžit'. Preto spočiatku t’ažšie hl'adala tón pravdivosti pri stvárňovaní tej-ktorej úlohy.

Závan zmeny v obsadzovaní do rol nevinných slečiniek či súdružskou hrdostou planúcich komunistiek priniesla Canina v Johnsonovej komédii Volpone (31. 3. 1957). Alžbetínska komédia síce popiera vyššie predstavenú tézu, že Pappová nebola herečka klasického typu ani repertoáru, ale Canina je pre jej kariéru príznačná z iných príčin. Postava je totiž komickou rolou a zároveň rolou s povolaním, ktoré bude herečka $\mathrm{v}$ budúcnosti na javisku i pred kamerou stvárňovat pravidelne. Z Pappovej sa totiž onedlho stane predstavitel'ka tragicky zmyselných, ale i koketne vtipných žien, ktoré sa pre svoju morálku, správanie i zamestnanie dostávajú do rozporu s dobrými mravmi solventnej spoločnosti. Volponeho intímna priatel'ka Canina je práve kombináciou komediálnej úlohy a postavy lacnej ženy. Podl’a Vladimíra Štefka „mala výrazné črty benátskej vševediacej kurtizány“8 , i ked” dobová recenzia tvrdí, že „Miestami v interpretácii sa žiadalo väčšmi vyhrat’ patričnú rafinovanost', najmä pri pôsobivom zjave, vhodnom pre uvedenú úlohu“" ${ }^{\prime 9}$. Dochované fotografie ponúkajú pohl'ad na renesančne slobodomyselný zjav herečky s jasne prítomným erotičnom a výzorom, ktorý balansuje na tenkej hranici medzi nespútanou dievčenskostou a živelnou ženskostou. Už pri tomto výkone možno s vel'kou pravdepodobnostou uplatnit vyššie citované slová Stanislava Vrbku o herečkinom prirodzenom až samočinnom sexappeale. Pappovej prvý výrazný krok bol teda urobený a čakal už len na svoje rozvinutie. To však neprišlo okamžite.

\section{Zrod herečky}

Začiatkom šesṫdesiatych rokov mladá generácia martinských hercov - Ivan Letko, Slavo Drozd, Igor Hrabinský, Ján Lojdl Blanský, Štefan Halás, Helena Sudická, Eliška Nosálová a Elena Zvaríková Pappová - dospela do zrelého veku. K ich umeleckému rastu prispela najmä zmena dramaturgického kurzu, popri inom aj oprostenie sa od armádnej tematiky. Divadlo sa vrátilo k názvu Divadlo Slovenského národného povstania a aktívne reagovalo na uvol'nenie z područia neproduktívneho socialistického realizmu. Umelecké vedenie už mohlo siahat po širšom okruhu hier, nebránilo sa ani doteraz neprístupným textom angloamerických autorov, dramatikom absurdného a groteskného divadla či predstavitel’om prúdu existencializmu. Ani režisér už nezastával len funkciu oživovatel’a divadelnej ilúzie: prelom desatročí so sebou prináša návrat režijného individualizmu, v ktorom je smerodajná interpretačná koncepcia, nie navodenie dojmu fotografie života.

V týchto podmienkach prichádzajú do Martina dve režisérske osobnosti, ktoré sa okamžite pokúšajú súbor dostat’ z prepadliska ideologicky orientovaného divadla - Pavel Rímsky a Ivan Petrovický. Podla divadelného historika Vladimíra Štefka, „Obaja v zásade pokračovali v uvádzaní repertoáru, ktorý bol pre martinskú scénu charakteristický. Na jednej strane pokusy oživit' vel'koplátnové divadlo, dedičstvo Otta Haasa, (...) na druhej strane pokračovanie v línii komornej psychologickej hry. (...) Popri známych pevninách a istotách martinského súboru, najmä jeho dramaturgie a herectva, je tu aj pokus o prekročenie žánru komornej drámy smerom k divadlu

\footnotetext{
${ }^{8}$ ŠTEFKO, V. Divadlo, ktoré vzniklo : štyridsat' rokov divadla SNP v Martine. Martin : Osveta, 1984, s. 77.

${ }^{9}$ MELIŠOVÁ, B. „Volpone“ v Armádnom divadle. In Ciel’, 6. 4. 1957.
} 
básnickému a filozofickému. "10 Snaha o regeneráciu divadelného umenia sa dala badat’ aj v hereckom súbore, najmä v jeho mladej časti. „Viditel’ný náskok pred staršími kolegami mali v dikcii, plynulosti gesta, v prednese verša, v schopnosti javiskovej kompozície. Ich príprava, entuziazmus, sústredenie sa na javiskovú prácu nerozptylované príležitostami v rozvíjajúcej sa televízii a filme, spolu so skúsenostou starších kolegov spôsobili istú renesanciu hereckého prejavu (...)." ${ }^{\prime 11}$

Zmenu divadelnej atmosféry vycítila aj Elena Zvaríková Pappová. Konečne mohla uplatnit’ špecifiká svojho herectva, ktoré boli v pät’desiatych rokoch skôr prekážkou než výhodou. Z nenápadnej, tuctovej členky vel'kého ansámblu vyrástla aj vd’aka sústredenej práci dramaturgie a režisérov protagonistka súboru. Jej výzor i herecký register nadobudli zrelé kontúry, režiséri sa už neobávali zverovat jej tažiskové úlohy a jej umeleckú osobitost’ si začali pozornejšie všímat’ kritici. Zvaríkovej Pappovej talent sa prejavil najmä tým, že akcentovala vnútorný dramatizmus charakteristických čŕt jednotlivých rol a vedela ich primerane vyjadrit’ v diferencovaných žánrových polohách. Napríklad v inscenácii hry estónskeho dramatika Egona Ranneta Zblúdilý syn (19. 12. 1959) považoval Aleš Fuks jej kreáciu Anniky za vrchol premiérového večera. „Jej výkon usmerňoval text k žiaducej dramatickej l'ahkosti, k psychológii, ale nie psychologizovaniu, k vyjadreniu zložitosti l’udského života ženy, ktorá miluje, ale nezradí svoju vlasț." ${ }^{\text {12 }}$

Zvaríková Pappová teda už nebola prototypom nevinnej baculatej naivky trpiacej následkami krutých životných skúšok, ale čoraz sebavedomejšie sa začala prehrávat’ od tézovitej jednostrannosti k zložitej l’udskej obsažnosti. Stala sa herečkou s osobnostným vyžarovaním, kultivovaným prejavom, civilnou výrazovou partitúrou i schopnost’ou zrozumitelne tlmočit náročné filozofické úvahy v dynamickom dramatickom prejave. Jej herecký typ sa postupne vyhranil do troch základných polôh, ktoré sa pribúdajúcimi úlohami a prácou režisérov s jej individualitou neustále rozširovali do pestrejších tónov či priam až poltónov. Prvou z nich boli osudové dominy - démonické ženy, vyvrhel'ky spoločnosti a záhadné existencie, ktoré vzbudzujú nedôveru nielen pre nepopieratel'né erotické fluidum, ale i pre nevyspytatel'né, akoby až besmi diktované konanie. Druhou sa stali ženy všedného bytia, ktoré by najradšej zotrvali v stereotypnom životnom chode, ale nepredvídané okolnosti ich prinútia odhal'ovat’ dovtedy netušené a neprebádané duševné sily. A napokon tretou polohou Zvaríkovej Pappovej bolo komediálne herectvo so širokým registrom javiskového humoru, od konverzačnej anglickej komédie plnej slovných bonmotov až po grotesku prezentujúcu temné stránky l'udskej osobnosti.

Jednu z príčin, prečo nebol herečkin talent spočiatku dostatočne využívaný, možno vidiet’ v tom, že nenašla "svojho“ režiséra. Aj ked' s ňou Ivan Petrovický a Pavel Rímsky kontinuálne pracovali, uznávali jej charakterizačné schopnosti a interpretačnú flexibilitu, klúčovú úlohu v jej kariére zohrali pohostinské réžie Juraja Svobodu. Ten jej ponúkol hned' niekol’ko dramaticky podnetných príležitostí so spoločným menovatelom: vždy išlo o bytosti iracionálne prepadajúce svojej vášni a vytrvalo idúce za ciel’om bez toho, aby hl'adeli na následky vlastného počínania. Svoboda naštudo-

\footnotetext{
${ }^{10}$ ŠTEFKO, V. Divadlo, ktoré vzniklo : štyridsat' rokov divadla SNP v Martine, s 85.

${ }^{11}$ Tamže, s. 92.

${ }^{12}$ FUCHS, A. Kdo zabloudil? In Divadelní noviny, roč. 3, č. 13, s. 5, 20.1. 1960. Z češtiny preložil K. Mišovic.
} 
Jean Paul Sartre: Väzni z Altony. Divadlo SNP Martin, premiéra 19. 5. 1962. Réžia Juraj Svoboda. Elena Zvaríková Pappová (Johanna). Foto archív SKD Martin. Snímka Jaroslav Barák.

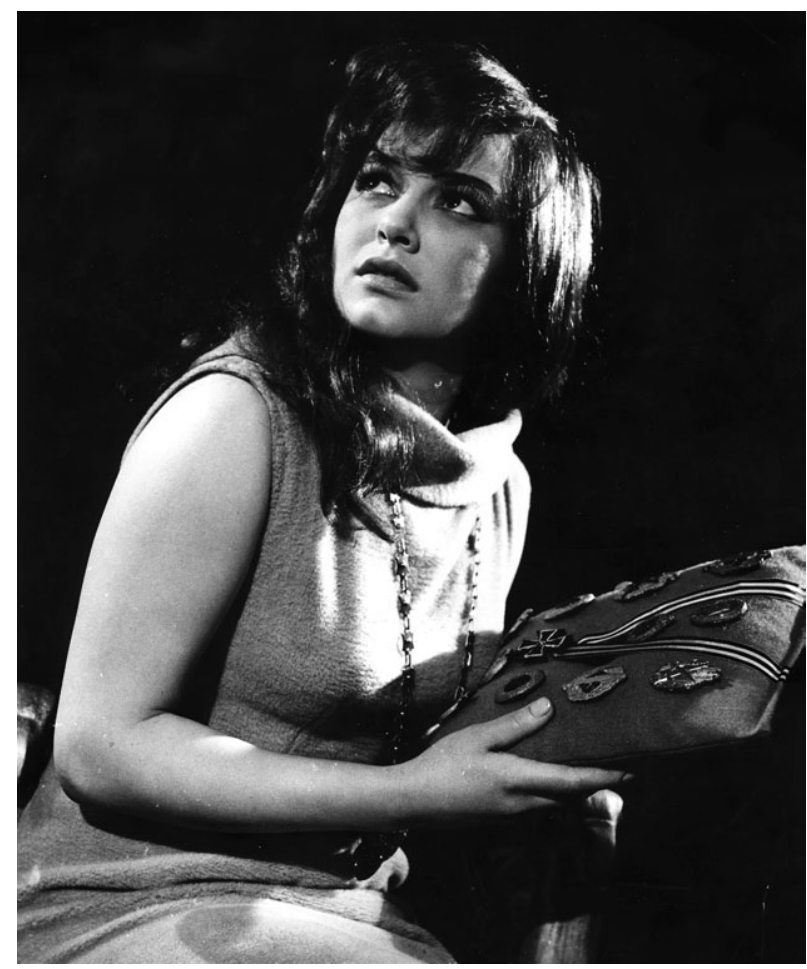

val v Martine v rozpätí rokov 1962 - 1965 šest’ inscenácií, z toho v piatich stvárnila ústrednú ženskú rolu. ${ }^{13}$

Po prvýkrát sa stretli pri uvedení Sartrovej filozofickej dišputy o vojnových prečinoch a zodpovednosti za zločiny proti l’udskosti Väzni z Altony (19. 5. 1962). Režisér redukoval filozofické pasáže rozsiahleho naratívneho textu a sústredil sa na určujúcu dejovú líniu, kladúc dôraz na herecky vecné pretlmočenie základnej idey hry. Dbal na to, aby účinkujúci ustriehli hranicu medzi nedramatickým intelektuálnym filozofovaním a prudkým emočným prežitkom. Kritik Milan Polák napísal: „Svoboda vedel viacerými premyslenými nápadmi navodit’ atmosféru, vygradovat’ dej a viest’ hercov $\mathrm{k}$ priliehavému, viac striedmemu a štylizovanému, než popisnému a naturalizujúcemu herectvu. Prejavilo sa to na postave Johanny, ktorú vytvorila Elena Zvaríková so vzácnou citlivostou, umiernenostou a možno práve preto akousi sugestívnou zovnútornenostou aj v tých najexponovanejších miestach. “14 Vladimír Štefko neváhal herečku po tomto výkone nazvat’ skutočnou oporou martinského súboru. ${ }^{15}$

Stretnutie so Sartrom zároveň poukázalo na to, že Zvaríková Pappová sa najlepšie cíti práve v hrách moderných autorov. To spozorovali aj režiséri, hostujúceho Juraja Svobodu nevynímajúc. Lenže ich nasledujúce javiskové stretnutia už nemali takú

\footnotetext{
${ }^{13}$ Juraj Svoboda s Elenou Zvaríkovou Pappovou (ale i inými martinskými hercami) v tomto období pravidelne pracoval aj v televízii, kde herečka pod jeho režijným vedením vytvorila niekol'ko klúčových rolí.

${ }^{14}$ POLÁK, M. Sartre na javisku. In Film a divadlo, 1962, roč. 6, č. 12, s. 13.

${ }^{15}$ Pozri ŠTEFKO, V. Divadlo, ktoré vzniklo : štyridsat' rokov divadla SNP v Martine, s. 105.
} 
umeleckú rezonanciu ako Väzňi z Altony. Nanajvýš problematicky vyznelo naštudovanie monumentálnej drámy Eugena O’Neilla Smútok pristane Elektre (20. 6. 1964). Svoboda precenil sily súboru a ani Zvaríková Pappová, napriek značným predpokladom, v plnej miere nenaplnila úlohu pomstou hnanej Lavínie, modernej analógie k antickej Elektre. Úprava textu sústredená na vyrozprávanie základnej príbehovej spleti a sploštenie Lavínie do podoby démonickej, nervnej a prchkej ženy obrali herečku o možnost’ vnútorne prehĺbit’ ostatné povahové črty ústrednej hrdinky.

No ak Svobodove réžie v Martine mali skôr klesajúce kvalitatívne tendencie, nemožno to isté konštatovat’ o výkonoch jeho protagonistky. Dôkazom toho je talianska melancholická komédia Eduarda de Filippa Filumena Marturano (15. 5. 1965). V hre o bývalej prostitútke, ktorá po rokoch spoločného života s druhom Domenicom túži po manželskom spečatení ich vzt’ahu, kreovala Zvaríková Pappová typ, ktorý sa postupne stával obligátnou súčastou súpisu jej divadelných, filmových i televíznych rol - povahou eruptívne, no mravnými postojmi počestné prostitútky, kurtizány, či prinajmenšom padlé ženy odsudzované meštiackou spoločnostou. Jednou z nich bola aj Filumena. Kým kritici unisono konštatovali monotónnost’ a žánrovú pomýlenost’ inscenácie, tak ako jej silnú stránku jednoznačne vyzdvihovali práve herečkin výkon. Už názov recenzie Juraja Váha Len výborná titulná postava hovorí o mnohom. ${ }^{16}$ Výstižnú charakteristiku kreácie ponúka najmä recenzia Štefana Šugára. „Elena Zvaríková je herečka, ktorá prináša do inscenácie vel'ké bohatstvo stavebných prostriedkov pre svoju rolu. Aj postavu Filumeny Marturano si vybudovala takto bohato a premyslene. Najočividnejší je tento jej prístup v bohatstve a rôznorodosti gesta, ktorým je schopná v neobvyklých a nezautomatizovaných spojeniach ozrejmit duševný stav a pocity svojej postavy. Zmyslom života Filumeny Marturano je vychovat' svoje tri nemanželské deti, pretože to slúbila Panenke Márii, a napokon dat im aj meno otca. Tento životný zápas Filumeny Marturano herečka zviditel’ňuje pohybom - mierne nachýlená dopredu akoby niesla na bedrách celú t’archu svojho života, ale zároveň akoby ako vlčica bola v neustálom strehu, aby mohla na život a na smrt’ bránit’ svoje víčatá. Materský cit ju vnútorne úplne spal'uje, ženie ju vpred a ked' sa dozvie, že jej manželstvo bude vyhlásené za neplatné, stojí síce na pokraji zúfalstva, ale so zatatými zubami bojuje d’alej. (...) A ked’ sa (...) po skončení malej rodinnej slávnosti rozplače - prvýkrát odvtedy, ako pozná Domencia - je to pointa, ktorú autor dôvtipne pripravil a ku ktorej herečka vývin svojej postavy naozaj doviedla. Filumena Marturano v hereckej kreácii Eleny Zvaríkovej je postava až pudovo elementárna, spoločensky dost’ neotesaná, intelektuálne primitívna, ale citovo bohatá, vášnivá, neústupná a o prudkosti svojho materského citu vedela divákov svojím hereckým výkonom presvedčit." ${ }^{17}$

Herečkin výkon musel skutočne rezonovat', taká obsiahla analýza jedného výkonu nebola totiž pri kritickej recepcii regionálnych divadiel bežná. Šugárove slová tak pomáhajú priblížit nielen konkrétny výkon, ale v širšom dramaturgickom rozhraní charakterizujú aj základný Zvaríkovej Pappovej herecký typ. Ako sme už naznačili, ženské charaktery v herečkinom podaní neboli jednofarebnými tézami, ale neprebádanými a nevyspytatelnými bytostami podliehajúcimi osídlam explozívnych vášní. Stanislav Vrbka ju v jednom z publikovaných medailónov charakterizoval: „Jej vý-

\footnotetext{
${ }^{16}$ VÁH, J. Len výborná titulná postava. In Film a divadlo, 1965, roč. 9, č. 15, s. 14.

${ }_{17}$ ŠUGÁR, Š. Priemernost’ je nesmrtelná aj v divadle. In Pravda, 11. 3. 1966, roč. 47, č. 69, s. 2.
} 


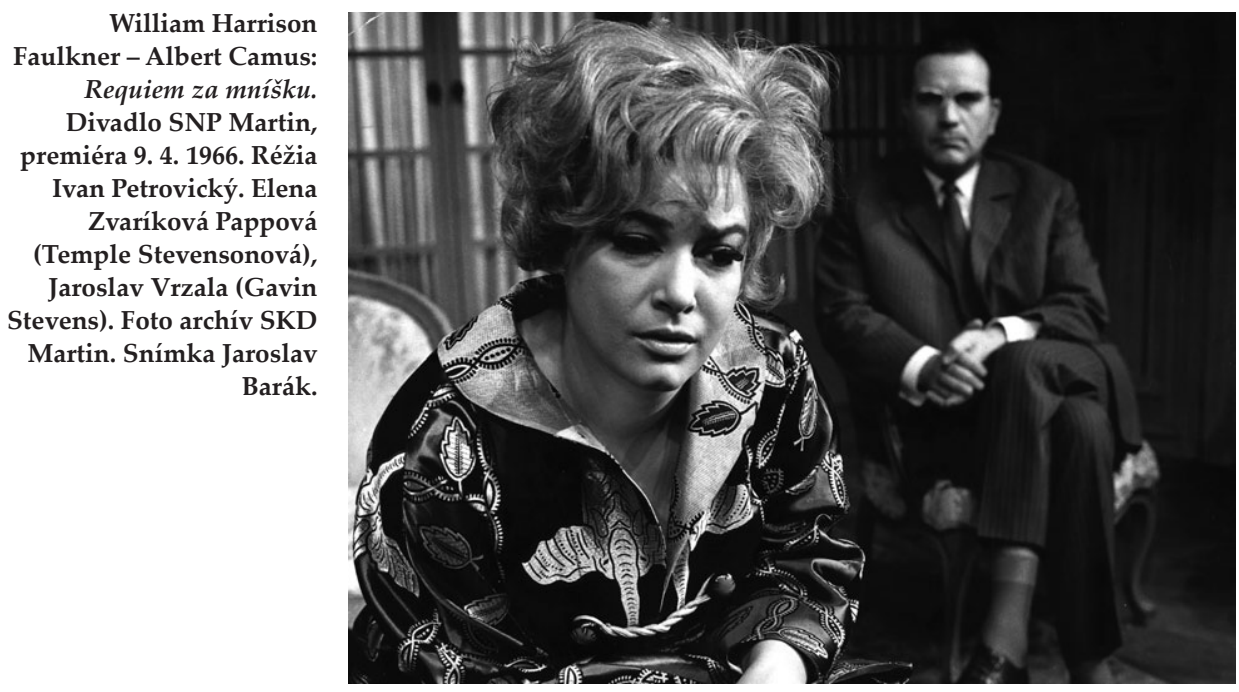

kony často pôsobili hranato, tvrdo, bola v nich akási plebejská neokrôchanost', zavše aj drsnost' s nádychom až naturalistickej surovosti. Ale, ked' ste nazreli pod povrch, často ste objavili drámu, ba neraz tragédiu doráňanej ženskej duše, ktorej sa nedarí vymanit’ z pút okolia a prekonat’ vlastnú slabost'. Čím viac jej herectvo vyzrievalo, tým častejšie sa stretávalo s rozporuplnými charaktermi. “18

Povahou nekonkrétne a myšlienkovými pochodmi nepredvídatel’né osudové hrdinky vedela hereckými prostriedkami zasadit do výrazovo jasne kontúrovanej interpretácie. Ženy strhávajúce masky počestného života, prerážajúce dno svojich vnútorných síl, vinníčky utekajúce pred minulostou, bytosti zasiahnuté freudovskými syndrómami, tam spočívalo Zvaríkovej Pappovej hlavné herecko-dramaturgické zacielenie. Nikdy to neboli frigidnou mravnostou zviazané dámy, konzervatívne posluhovačky dobrých mravov či názorovo nevyhranené spoločníčky "silnejšieho“ pohlavia. Zvaríková Pappová hrala vždy ich priame opaky - strindbergovsky animálne bytosti ocitajúce sa $\mathrm{v}$ extrémnych existenčných súbojoch, $\mathrm{v}$ ktorých sa musia spol’ahnút výhradne na svoje vrodené inštinkty. Pravidelne stvárňovala ženy mimo noriem, dominy, ktoré sa už nemôžu začlenit’ spät’ do bežného chodu života. Taká bola jej podmanivá Temple v Camusej dramatizácii Faulknerovej beletrie Requiem za mníšku (9. 4. 1966), s neustále prítomným tajomnom ukrývajúcim sa za dvojznačnými dramatickými pauzami, už spomenuté Lavínia a Filumena, aj frivolná slúžka Lujza z Thomasovej detektívky Osem žien (11. 4. 1964) či neskôr Vasilisa Karpovna z Gorkého Na dne (16. 11. 1967) a Maxine z Williamsovej Noci s leguánom (20. 4. 1968).

Na rozdiel od Juraja Svobodu, ktorý herečku obsadzoval do úloh osudových žien, Pavel Rímsky dbal na rozvinutie lyrickejšieho tónu jej hereckej škály. Po agilnej bojovníčke o životné štastie Helene zo Shakespearovho Sna májovej noci (1. 7. 1961) to bola najmä Val'a v Arbuzovovom Irkutskom príbehu (13. 10. 1962), na začiatku šest’de-

${ }^{18}$ VRBKA, S. Elena Zvaríková - od mladosti pani herečka. In Listy SND, propagačný dvojmesačník, 1989 -1990 , č. 5 , s. 8 . 


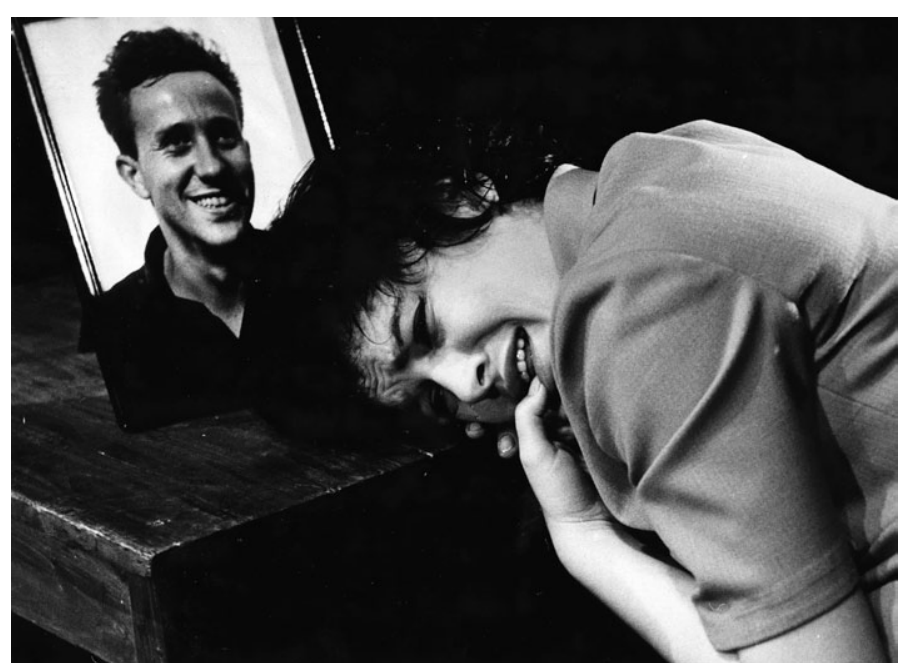

Alexej Nikolajevič

Arbuzov: Irkutský príbeh.

Divadlo SNP Martin, premiéra 13. 10. 1962.

Réžia Pavel Rímsky. Igor Hrabinský (Sergej), Elena Zvaríková Pappová (Val'a). Foto archív SKD Martin. Snímka Jaroslav Barák.

siatych rokov najinscenovanejšej sovietskej hre v tzv. východnom bloku. Rola predavačky s nedobrou povestou, žijúcej v kolektíve robotníkov na stavbe priehrady na Angare, ktorá cez meandrovité životné peripetie dospieva od l’ahkovážneho dievčata k podobe racionálnej ženy a najmä k profilu hrdej sovietskej občianky, patrila v danej dobe medzi módne herecké príležitosti. Možnost' stvárnit ju dostávali výhradne protagonistky súborov, schopné nenápadnými hereckými finesami obsiahnut náročný vnútorný boj i následný emočný prerod komplikovanej ženskej duše. Na Slovensku popri Márii Královičovej zo SND, Eve Rysovej z Trnavy, alternantkách z Košíc Judite Vicianovej a Elene Volkovej či Anne Ferenczyovej z Komárna dokázala zaujał aj martinská predstavitel'ka. Rudolf Mrlian o jej výkone konštatoval: „Farbitost’ postavy závisí od postoja a schopnosti herečky, od jej osobitného videnia, názorov, charakteru a vnútornej sily. Elena Zvaríková preniesla svoju Val’u do nášho prostredia, pohrala sa s dievčenskou roztopašou, neviazanost'ou, vyskúšala pevnost' i odolnost' našich chlapcov, postavila sa zoči-voči okolitej spoločnosti, chcela íst' dokonca proti nej. A predsa našla východisko v čestnom, otvorenom vztahu Sergeja, ktorý jej vyrástol nad všetkých a nad všetko, v ňom a s ním našla svoje štastné miestečko, svoj kúsok životnej pôdy. Na prvý dojem bol u nej každý prejav, prvok samozrejmý, nenútený, ale skrýval v sebe znásobenú silu umeleckého zážitku. Bolo to hlavne preto, že Zvaríková vážila presnou mierou svoj cit, iste aj presvedčenie, no nadovšetko vonkajší prejav obohacovaný významovo i umelecky podčiarknutým detailom. A tak sa nám pomaly odvíjalo zamotané klbko, pričom sme ani na chvílu nestratili spred očí jednotlivé nitky, ktoré pospolu vytvárajú celok. Hodno preto vyzdvihnút osobité uchopenie a pochopenie postavy i jej umelecké zvládnutie. “19

Špecifické miesto $\mathrm{v}$ martinskej ére herečkinej kariéry patrí komediálnym kreáciám. Spočiatku sa zdalo, že pre plnoštíhlu postavu ostane predstavitel'kou humorných figúrok - síce s bystrými očami a pohotovými reakciami, ale i tak s nepresiahnutými métami od typovej ku charakterovej komičke. Herečka však aj v tejto oblasti

${ }^{19}$ MRLIAN, R. „Irkutský príbeh“ v Martine. In Pravda, roč. 43, č. 358, s. 3, 29. 12. 1962. 
prekvapila. Postupom času sa predstavovala ako suverénna interpretka koketných i duchaplných milost’paní, ale súčasne dokázala svoje herectvo vyladit’ aj do ostrých čŕt grotesky a typovej karikatúry. V týchto prípadoch sa nebála poprieł svoje ženské prednosti, alebo naopak, exponovat’ ich ako účinnú zbraň ekonomickej či aspoň komickej taktiky. S nonšalantnost’ou sa prezentovala aj ako precízna tlmočníčka bonmotov v konverzačných komédiách anglického salónneho štýlu. V Líze Doolitlovej v Shawovom Pygmalionovi (27. 10. 1961) vystihla neohrabanost' prejavu londýnskej kvetinárky, ktorá si rýchlo osvojí noblesu a šarm urodzenej britskej lady. Podobne v Anouilhovom Bále zlodejov (8. 4. 1967), Simonových Bosých nohách v parku (6. 11. 1965) či Wildovej komédii Je dôležité mat’ Filipa (31. 12. 1964) koncentrovala pozornost' na plynulý a l'ahký rytmus reči, vecnost’ vravy, briskné tlmočenie významov a najmä na vystihnutie point, ktoré však vyslovovala s osobitou samozrejmostou, bez očividného akustického akcentu. Pritom si uchovávala spontánnost prejavu, zbytočne nepsychologizovala a svoje herectvo podriad’ovala štýlovej čistote inscenácie. Tieto tóny úspešne uplatňovala aj v rolách, kde si neobliekala honosné aristokratické či aspoň meštiacke róby, ale obyčajné odevy akoby vypožičané z vlastného šatníka. Teda obdobne ako vo vážnejšom repertoári, aj v komediálnom žánri vyrástla zo Zvaríkovej Pappovej autentická predstavitel’ka širokej škály sociálneho statusu postáv.

\section{Ozvláštnený realizmus Eleny Zvaríkovej Pappovej}

Elena Zvaríková Pappová sa v priebehu šest’desiatych rokov stala klúčovou interpretkou v inscenáciách režisérov Pavla Rímskeho, Ivana Petrovického i Juraja Svobodu. Ale ak našla skutočne spriazneného režiséra, tak to bol jej niekdajší spolužiak z ODK Miloš Pietor. Už od čias jeho pohostinských martinských réžií bol v herectve Zvaríkovej Pappovej badatel'ný jasný progres (čo paralelne začali využívat' aj ostatní režiséri), ktorý plynulo pokračoval i po roku 1962, ked’ Pietor nastúpil do interného pomeru v DSNP. Umelecký naturel herečky absolútne kontroval jeho režijnému videniu. Pietor totiž do slovenského divadelníctva nepriniesol výrazový a formálny experiment, naopak, jeho inscenácie vychádzali z dôkladného poznania metódy psychologického realizmu, ktorú však interpretoval z modernejšieho uhla pohl'adu. Pietrov realizmus už bol syntézou prvkov avantgardy a súčasných divadelných prúdení s dôkladným realistickým čítaním textu. Vladimír Štefko jeho poetiku výstižne nazval „ozvláštneným realizmom“: „Nebola to len transkripcia životných javov na javisko, ale dôraz na psychologickú prepracovanost' postáv, najmä ich vzájomných vztảahov takým spôsobom, aby sa nestrácala ich divadelno-estetická účinnost', aby život na javisku bol kondenzátom, extraktom, básnickým zobrazením reality. V jeho poetike mala dôležité miesto skratka, hutnost', precíznost' motivácie konania postáv, úcta $\mathrm{k}$ autorovmu dielu i myšlienke, k slovu, výtvarné i poetické až lyrické cítenie. ${ }^{\text {20 }}$

Ozvláštneným realizmom by sme mohli nazvat’ aj herecký sloh Eleny Zvaríkovej Pappovej. Až Pietor v nej totiž odhalil zrelú charakterovú herečku, takže najvýraznejšie umelecké vítazstvá a profilové kreácie martinského obdobia dosiahla práve $\mathrm{v}$ jeho réžiách. Bol to on, kto z typovej herečky stvoril charakterovú herečku. Z ich

${ }^{20}$ ŠTEFKO, V. Divadlo, ktoré vzniklo : štyridsat' rokov divadla SNP v Martine, s. 112. 


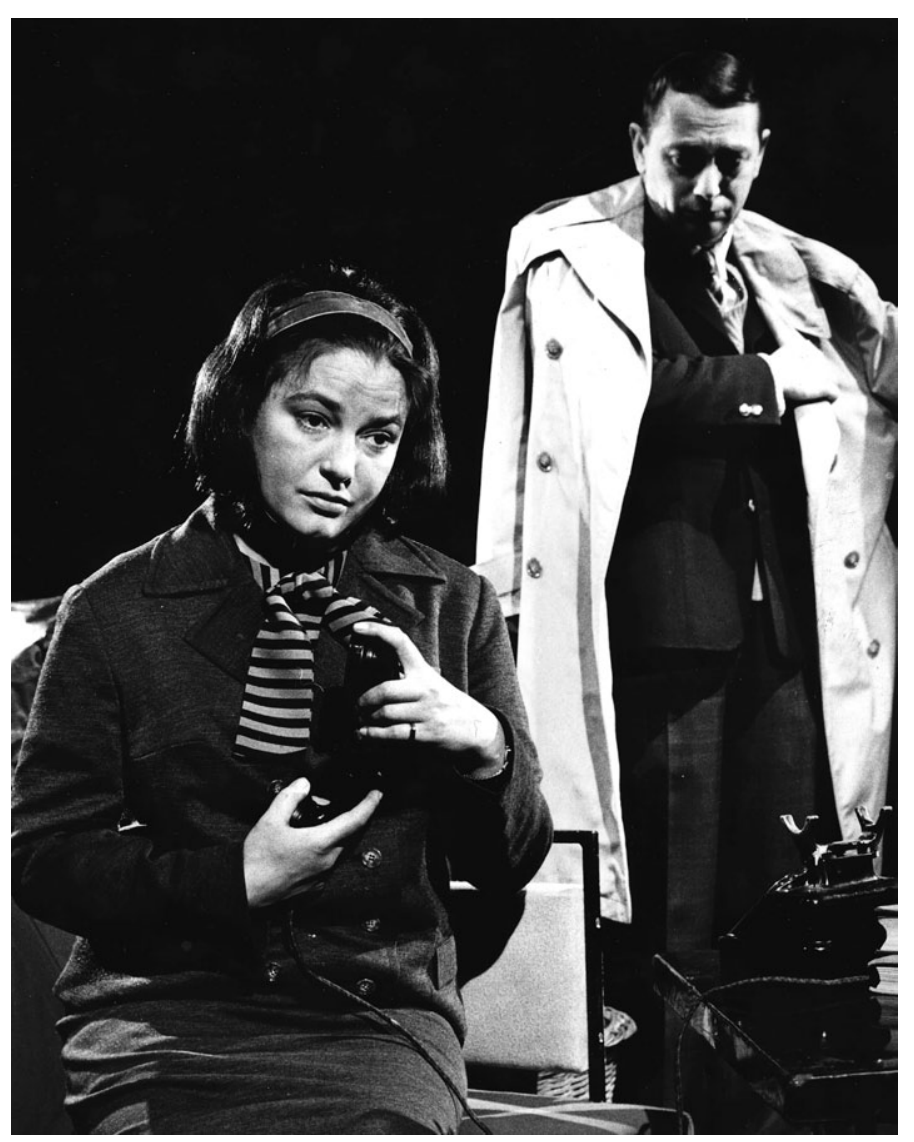

Murray Schisgal:

Strojopis. Divadlo SNP Martin, premiéra 24. 6. 1967. Réžia Miloš Pietor. Elena Zvaríková Pappová (Sylvia), Ivan Folkman (Paul). Foto archív SKD Martin. Snímka Jaroslav Barák.

vzájomných stretnutí treba osobitne spomenút najmä tri diela - inscenáciu dvoch hier Murraya Schisgala Strojopis a Tiger (24. 6. 1967) a dve naštudovania ruských klasických titulov - Čechovove Tri sestry (21. 1. 1967) a Gorkého Na dne (16. 11. 1967).

V Schisgalových štýlovo odlišných jednoaktovkách našiel Pietor tematický priesečník: uviaznutie človeka v životnom stereotype a neschopnost’ aspoň na chvílu pozastavit zabehnutý cyklus. V Strojopise sa stretávame s dvojicou administratívnych úradníkov, ktorých celý život prebehne za pracovným stolom. Vidíme ich od aktívnej mladosti až po šedivú starobu, a to všetko v nenápadných časových posunoch. Dramatik tak s miernou grotesknou hyperbolou poukázal na zmechanizovanie života a následnú l'udskú rezignáciu. Tiger je zase miniatúrna čierna komédia o násilníkovi, ktorého zvedie jeho vlastná obet. Pietor v plnej miere rešpektoval poetiku hier a viedol ju v ironickom nadhl'ade, dbajúc najmä na civilný prejav predstavitel'ov oboch dvojíc - Eleny Zvaríkovej Pappovej a Ivana Folkmana. Sylviu v Strojopise herečka spočiatku tvarovala ako energickú, i ked’ emočne labilnú dievčinu plnú ideálov. Štefan Šugár konštatoval: „Prehrávanie vonkajškových, komických znakov charakteristiky postavy však (...) rýchlo zmení za decentný výraz pre zvnútornený a chápavý pohl'ad do zložitého a chaotického citového sveta mladej osamelej ženy, ktorá dozrieva 
vo vyrovnávaní sa so svojím l’udským údelom. Pretože vnímame neustále tento silný prúd citového života postavy, ktorý nám svojím herectvom plasticky zobrazuje, takmer si neuvedomujeme jej premeny od pochabého dievčiska k starej žene (...), ktorá sa vyrovnala so svetom bez hystérie a hluku; uzlík neuskutočnených nádejí a snov je odložený kdesi na dno srdca a spolu so svojou trpkostou si ho bez slova odnesie na druhý svet. “21 V druhej aktovke herečka stvárnila Glóriu, obet’ muža, ktorý si celoživotné neúspechy u žien kompenzuje ich únosmi. Hereckú autentickost’, úspešne využitú v Strojopise, tu Zvaríková Pappová mohla obohatit aj o prvky komického odstupu od roly malomeštiačky ocitajúcej sa v nepredvídanej životnej situácii. „S nevšednou chutou, pôžitkom a komediálnym ostňom vyhráva svoju Glóriu od hysterických prejavov strachu spôsobnej paničky a vzornej manželky pred znásilnením, ktorá svojím ženským inštinktom skoro prehliadne skutočnú situáciu, ovládne ju svojou nenásytnou tužobou uskutočňovat’ sa v pomoci druhým, až napokon skončí na mieste, ktorému sa na začiatku so živočíšnym strachom bránila - totiž v Benovej posteli." 22

Miloš Pietor zaujíma v dejinách slovenského divadelníctva nezastupitelné miesto aj ako inovatívny režijný interpret ruskej klasiky. K dedičstvu Čechova či Gorkého totiž nepristupoval s pietou či sentimentalitou ako jeho predchodcovia, ale na javisku prezentoval postavy umárajúce sa v marazme moderného sveta. V Troch sestrách i v o sezónu mladšom $\mathrm{Na}$ dne hovoril výsostne vecným, často až tragikomickým tónom o sklamaniach, nenaplnených túžbach a bezvýchodiskovosti životných osudov ako o odraze svojej doby. Na hrdinov Čechovovej drámy sa pozeral nepateticky, lutoval ich, ale vinu za uviaznutie ich životov prisudzoval aj im samým. Inscenácia slovami Vladimíra Štefka „,akoby vravela s Čechovom, že o dobre netreba len snívat, ale treba oň celým svojím životom bojovat" ${ }^{\prime 23}$. Preto nedovolil, aby do hereckých výkonov prenikli prvky sebal'útosti. Naopak, s protagonistami akcentoval aj povahové neduhy postáv, ktoré zapríčiňovali letargiu ich neproduktívnych životov. Spomedzi účinkujúcich vynikla predovšetkým neštastná, ale v momentoch neustriehnutej vášne nepríjemná až antipatická Máša Eleny Zvaríkovej Pappovej, ktorá „,nebola stelesnením krásy, dobra, poézie, ktorá trpí viditel’ne neštastným manželstvom. Jej Máša bola aj otrávená, unudená, zlostná, rozkričala sa pri najmenšej kolízii. (...) Jej láska k Veršininovi nebolo priezračné čisté citové vzplanutie, bolo v nej čosi zábavky, krátenia dlhej chvíle i túžby po dobrodružstve. “24 Herečka dostala príležitost’ naplno rozvinút nuansy svojho dramatického umenia: jemné psychologické prechody medzi kontrastnými emočnými polohami, pritom nie prudké strihy, ale kontinuálne celky pozorne škálovaných rozporných psychických odtieňov a rozpoložení. Ako zhodnotila Eva Galandová: „Máša je bytost', ktorú trpko poznačila samota, nepochopenie, do ktorého ju priviedlo l’udské a citové sklamanie; zvádza sama so sebou úporný nervný boj o sebanaplnenie, o záchranu pred rezignáciou. ${ }^{25}$ Femme fatale odetú v jednoduchých dlhých čiernych šatách, so zopnutými tmavými vlasmi a s nezúčastneným, až otupeným pohl'adom očí vyplývajúcim zo životnej pasivity

\footnotetext{
${ }^{21}$ ŠUGÁR, Š. O outsideroch spoločnosti. In Kultúrny život, roč. 22, č. 30, s. 9, 28. 8. 1967.

${ }^{22}$ Tamže.

${ }_{23}$ ŠTEFKO, V. Divadlo, ktoré vzniklo : štyridsat' rokov divadla SNP v Martine, s. 118.

${ }^{24}$ Tamže, s. 117.

${ }^{25}$ GALANDOVÁ, E. Tri sestry v Divadle SNP. In Smena, roč. 20, č. 22, s. 4, 26. 1. 1967.
} 


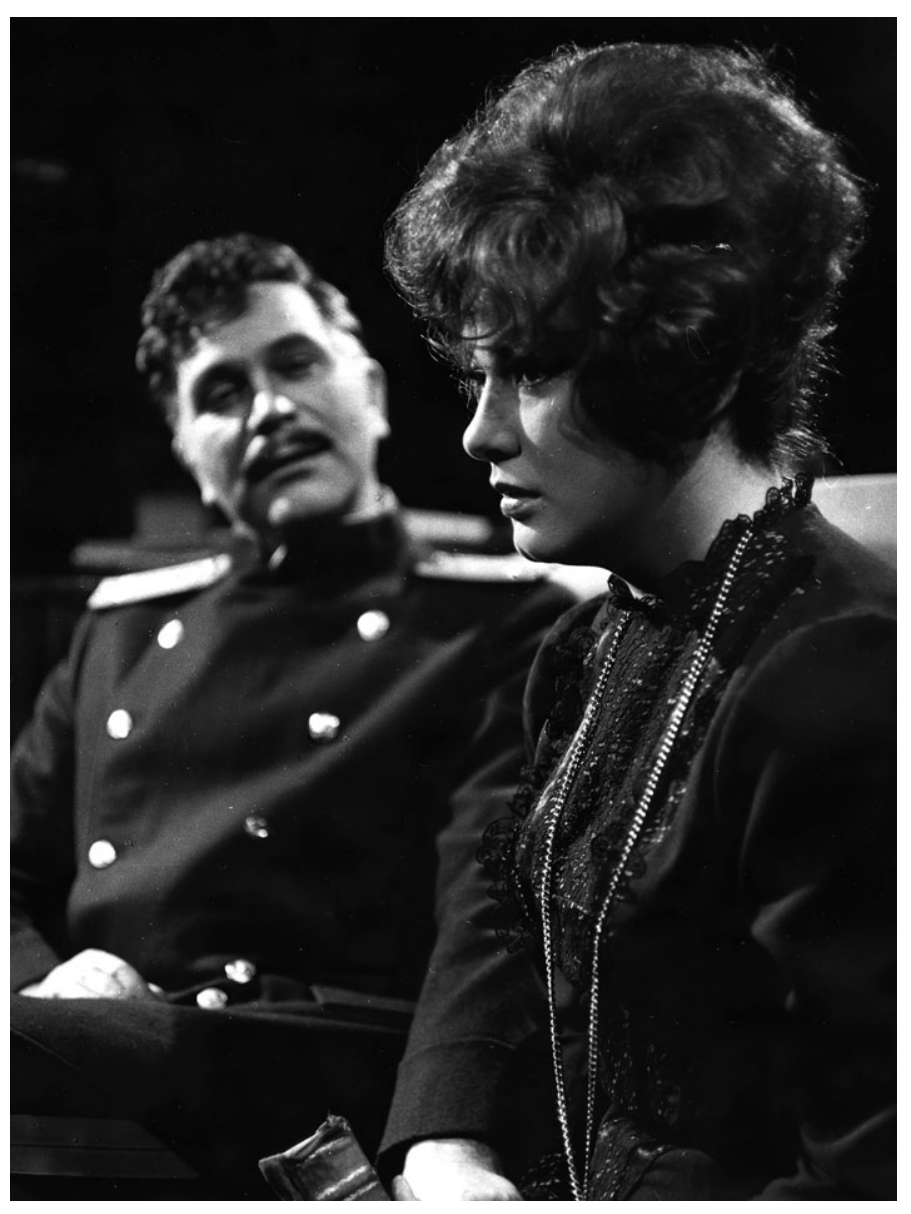

Anton Pavlovič Čechov: Tri sestry. Divadlo SNP Martin, premiéra 21. 1. 1967. Réžia Miloš Pietor. Jaroslav Vrzala (Veršinin), Elena Zvaríková Pappová (Máša). Foto Archív SKD Martin. Snímka Jaroslav Barák.

prirovnal Emil Lehuta k Serovovomu portrétu herečky Marije Jermolovovej, pričom Zvaríková Pappová sa akoby inšpirovala nielen „zovňajškom slávnej ruskej tragédky (...), ale aj jej psychologickou sústredenostou (...) a vznešenostou, ktorou prevyšuje svoje okolie“" ${ }^{26}$

V Čechovovej postave vytvorenej v spolupráci s Milošom Pietorom našla Zvaríková Pappová komfortnú zónu pre danosti charakterovej herečky, interpretky, ktorá dokáže prirodzene poukázat’ na záhadnú dvojznačnost' postavy, predstavit’ ju v hutnom vonkajškovom prejave, vyhýbajúc sa pritom prízemnej hystérii a sústred’ujúc sa na polohy najintímnejšieho privatissima. Za vzácne konzistentný herecký portrét získala v roku 1968 prestížnu Cenu Andreja Bagara. Naplnili sa tak slová Evy Galandovej, ktorá už po premiére konštatovala: „Jej kreácia je najbližšie k súčasne ponímanému čechovovskému herectvu a ponímaniu, ktoré Pietor režijnými prostriedkami naznačil: k večnej a súčasnej dráme nenaplnených túžob. ${ }^{27}$

\footnotetext{
${ }^{26}$ LEHUTA, E. Zo zápisníka Emila Lehutu. In Slovenské pohl'ady, 1968, roč. 84, č. 3, s. 149.

${ }^{27}$ GALANDOVÁ, E. Tri sestry v Divadle SNP.
} 

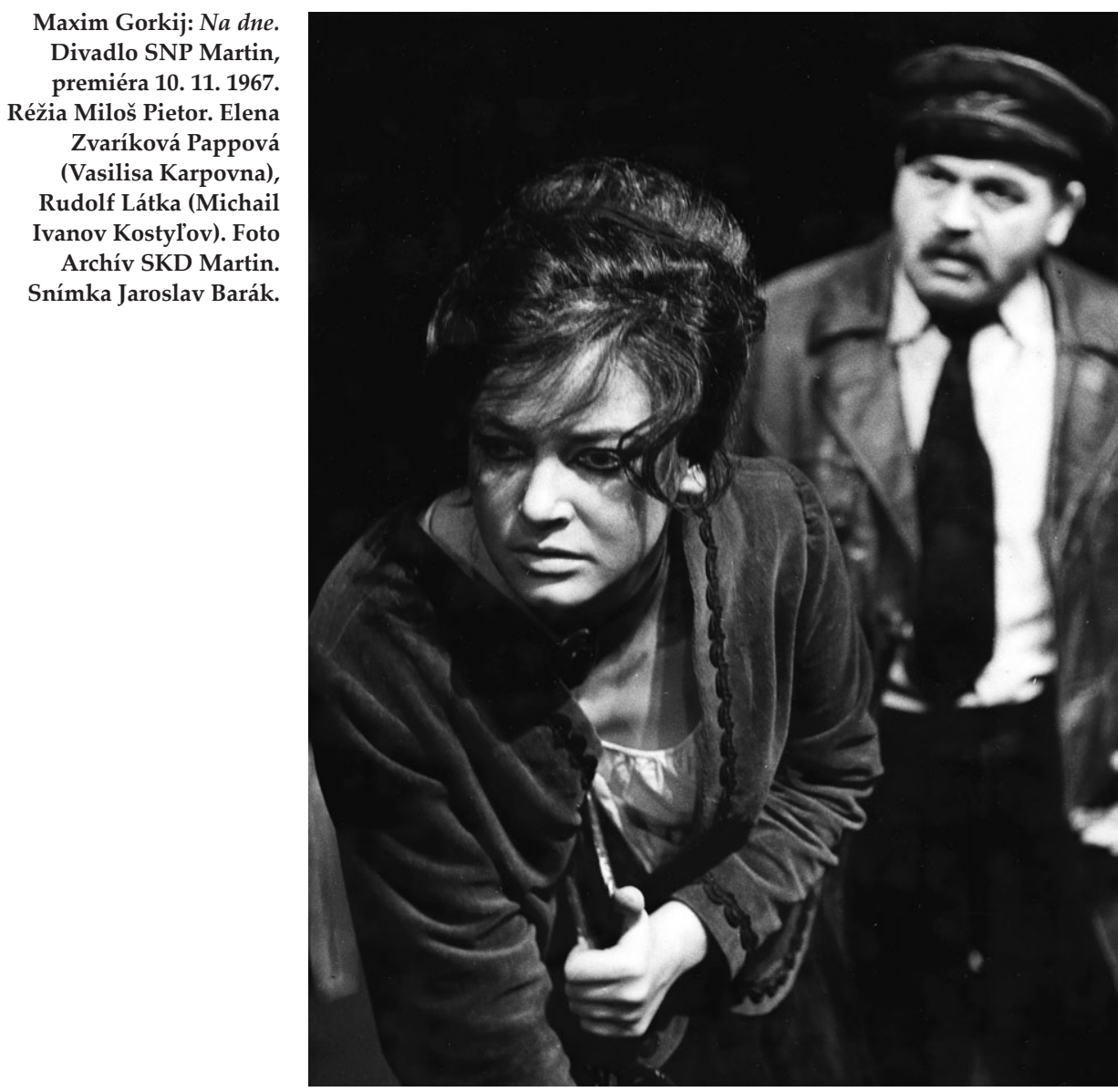

Podobne nepietnym a hlavne neideologickým pohl’adom vyložil Pietor aj dobovo protežovanú hru Maxima Gorkého $\mathrm{Na}$ dne. Drámu nevnímal ako súcitný žánrový obrázok o bosákoch, ktorí sa ocitli na l’udskom i existenčnom dne. V texte akcentoval motívy neschopnosti komunikácie, povahovej nedvižnosti, egocentrizmu a osamelosti človeka. V Gorkého príbehu našiel až prvky absurdnej drámy o večnom čakaní na lepší život, ktorý stále neprichádza. V semenisku hriechu a biedy stvárnila Zvaríková Pappová manželku majitel’a noclahárne Vasilisu Karpovnu. Bytost’ nekompromisnú a k okolitému svetu až krutú, ale pod príkrym povrchom ukrývajúcu senzitívny l’udský cit. Ako uvádza Vladimír Štefko, „nebola iba zlou ženou, strigou, postrachom nocl'ahárne, ktorú vie skrotit iba Vaska Pepel', ale ženou, ktorá by strašne rada unikla z tohto prostredia, ktorá si po kúsočkoch doslova kradne zo života radostnejšie, príjemnejšie chvíle, ale nadovšetko štipky porozumenia" ${ }^{28}$

O Zvaríkovej Pappovej sa začalo písat’ a hovorit’ v širších reláciách. Kritika oceňovala jej javiskové kreácie, značné herecké posuny i nevyčerpatel’nú tvárnost' cha-

${ }^{28}$ ŠTEFKO, V. Divadlo, ktoré vzniklo : štyridsat' rokov divadla SNP v Martine, s. 119. 
rakterizačného talentu a jej výkony konfrontovala s prácou bratislavských kolegýň. Prechod umelkyne do Bratislavy tak nebol ničím prekvapivým. S martinským divadlom sa rozlúčila úlohou, ktorá bola pre jej herecký typ viac ako príznačná - Maxinou z Williamsovej Noci s leguánom (20. 4. 1968), rolou napísanou v osnovách moderného realizmu, s príchutou freudovskej psychoanalýzy. V réžii Ivana Petrovického tak bola na javisku opät ženou-maximalistkou, komplikovaným stvorením vystatujúcim sa pred okolím svojou živelnostou a povahovou nevyberanost’ou. No v skutočnosti zranitel’nou, či vlastne už zranenou ženskou dušou. Ako napísal Martin Porubjak, ,jej Maxine je energická a hrubá, aby sa jej vzápätí zlomil hlas v zúfalstve opustenosti, je vulgárna, aby zakryla nežnost́, je egoistická a prísna, aby o chvílu mohla odpustit’. Mnohoznačnost’ tejto postavy (...) stelesnila s vel'kým zmyslom pre hodnovernost’ a pravdivost', podarilo sa jej tak obsiahnut’ vnútorne vel'mi rozpornú postavu - napriek jej rozpornosti - v celej šírke a pritom naozaj presvedčivo. “29 Maxine tak bola dôraznou bodkou za štrnástimi sezónami na martinskej scéne, kde sa z tuctovej predstavitel'ky vedl'ajších úloh zrodila kl'účová herecká osobnost’ dobového slovenského divadelníctva.

\section{Návrat do Bratislavy}

Od 1. 1. 1969 sa Elena Zvaríková Pappová stáva členkou činohry SND. Do divadla, v ktorom v prvej polovici pätdesiatych rokov neisto začínala, prichádza ako herečka so zvučnou povestou. Lenže na rozdiel do svojich predchodkýň a predchodcov Hany Kováčikovej, Márie Královičovej, Evy Krížikovej, Zdeny Gruberovej, Ctibora Filčíka, Ela Romančíka, Štefana Kvietika či manželov Kronerovcov, ktorí podobne ako ona zariskovali a prestúpili z turčianskeho javiska do pulzujúceho bratislavského života, prišla ako zrelá žena, na ktoré myslel máloktorý dramatik. Činoherný súbor SND navyše disponoval dostatkom jej generačných rovesníčok - Zdenou Gruberovou, Evou Polákovou, Vierou Topinkovou a najmä jej švagrinou, typologicky príbuznou Evou Krížikovou. K postávam v strednom veku sa zároveň v tom čase ešte hlásili aj o niečo staršie kolegyne Mária Královičová, Eva Kristinová a Viera Strnisková. Všetky boli vyprofilovanými umelkyňami, ktoré si v rozvrstvenom, mnohopočetnom ansámbli našli svoje miesto i režiséra. O hereckých dispozíciách čerstvej členky divadla nemohol síce nikto pochybovat', ale na novom pôsobisku musela začínat od nuly.

Svojbytnú pozíciu si hl’adala t’ažko. Interní režiséri staršej generácie Jozef Budský, Tibor Rakovský a Karol L. Zachar už mali svoje dvorné protagonistky. Zvaríkovej Pappovej civilné, odpoetizované herectvo neladilo s Budského emočne sýtym divadlom vel'kého plátna, ani s Rakovského scénickou intelektuálnou básnivostou, a už vôbec nie so Zacharovým vnímaním javiskového diela ako akvarelovo retušovaného obrazu reality. Oporu našla aspoň v mladšej, postupne sa etablujúcej generácii - Pavlovi Hasprovi, Petrovi Mikulíkovi i v činohre pravidelne hostujúcom Jozefovi Palkovi, teda v režiséroch komorného a zavše i moderného repertoáru. Všetko nasvedčovalo tomu, že by vd’aka integrálnej spolupráci s týmito tvorcami mohla ohlásit’ renesanciu svojich martinských úspechov.

Ešte pred nástupom do súboru herečka hostovala na Malej scéne SND v Mikulí-

${ }^{29}$ PORUBJAK, M. Williams v Martine. In Kultúrny život, roč. 23, č. 22, s. 5, 31. 5. 1968. 
kovej inscenácii drámy Harolda Pintera Návrat domov (7. 12. 1968). Autor v hre zobrazuje perifériu l'udských hodnôt, kde kombinuje krutost' vzájomnej psychickej tyranie postáv s absurdnostou ich bytia. Zvaríková Pappová v intenciách martinských úloh stvárnila symbol dobyvačného, osudového a najmä hriešneho ženstva, ktoré svojím prirodzene erotizujúcim vyžarovaním dráždi čisto mužský kolektív hry. Ruth príchodom do manželovho rodného domu a zoznámením sa s jeho príbuznými postupne odhal'uje svoju nečestnú minulost’ a stáva sa tak spúštačom absolútnej deštrukcie dovtedy aspoň provizórne stabilných rodinných pilierov. Ako napísal Zoltán Rampák, bola to „rola, kde sa herecký výkon pohybuje stále na nebezpečnej hranici vulgárnosti. Zvaríková svojím výkonom túto hranicu neprekročila, napriek tomu, že mala podstatne menej textu než jej mužskí partneri a že tažisko jej výkonu muselo zostat' v oblasti gestickej a mimickej. “30 Jej Ruth pútala exteriérom tajomnej, nejednoznačnej bytosti. Bola eroticky podmanivou dominou, pritom vonkajškovo neexpanzívnou, sústredenou na neverbálnu stránku hereckého výrazu. „Neurčitý úsmev na tvári, tupá rezignácia v očiach - alebo nevyslovené utrpenie a otázka v pohlade. Stále sa môžeme pýtat', kto je a odkial' prichádza, alebo kam odchádza a prečo zostáva. Prijíma svet a agresivitu voči svojej osobe a zároveň ju tajomným spôsobom odráža. Žije svoj vlastný život, do ktorého nemôže nikto preniknút', nikto ju nemôže pochopit." Podobné ponory do patologicky deformovanej psychiky postáv a špecifický autorov jazyk však neboli vlastné všetkým hercom národnej scény, takže pre Zvaríkovú Pappovú to bol vd’aka jej predošlým skúsenostiam s modernou dramatikou smelý prológ bratislavskej etapy. Premiérové recenzie zároveň priniesli nielen názory o jej hereckej dominancii v inscenácii, ale aj o opodstatnenosti angažovania herečky do súboru. ${ }^{32}$

Zmena divadla nespôsobila zmenu hereckého typu. Aj bratislavskí režiséri v Zvaríkovej Pappovej objavili precíznu tlmočníčku ženského nepokoja, vášnivosti, interpretku schopnú neteatrálnym vonkajškovým prejavom vyjadrit’ eruptívne životné otrasy žien na pokraji morálnej priepasti. A to nielen v hrách vystavaných na psychologickej kauzalite dramatických prostriedkov. Dôkazom bola nasledujúca inscenácia v réžii Petra Mikulíka, surrealistická groteska Rogera Vitraca o výsmechu z pokrivenej meštiackej morálky Viktor alebo vláda detí (30. 3. 1969). V pokryteckom panoptiku stvárnila herečka postavu Thérése - pred verejnostou príkladnú manželku, ale v skutočnosti nervnú a nevernú ženu-vampa. Milan Polák konštatoval, že spolu s Vierou Strniskovou, predstavitel'kou frigidnej Emilie, došla Zvaríková Pappová najd’alej vo výstižnej typovej špecifikácii, ked” „na malej ploche charakterizovala výrazne frivolný typ nemravnej meštiačky, žijúcej pod maskou počestnej ,normálnosti' . "33 Postavy morálne pokrivených žien teda nad’alej dominovali herečkinmu súpisu rol.

Na základe prvých úspechov by sa mohlo zdat', že Zvaríková Pappová sa v Bratislave postupne etablovala. Porovnanie jej hereckých príležitostí s činnostou jej kole-

\footnotetext{
${ }^{30}$ RAMPÁK, Z. Nič nového u nás s Pinterom. In Film a divadlo, 1969, roč. 13, č. 2, s. 24.

${ }^{31}$ ŠTEFKO, V. Divadlo ironie a relativity. In Divadlo, 1969, č. 2, s. 77. Z češtiny preložil K. M.

${ }^{32}$ Napríklad Móric Mittelmann Dedinský poznamenal: „Vol’akedy sa také pohostinské vystúpenia hodnotili so zretel’om na možné angažmán. V prípade Zvaríkovej to robit’ netreba. Jej zdržanlivá výraznost', jej trpko smutná a pritom lascívne dráždivá vášnivost', jej istota v odhal’ovaní tónov a poltónov v geste, mimike i v hlase jej už dávno garantovali miesto v súbore SND, ak má tento súbor byt’ ozaj miestom sústredenia najlepších síl slovenského herectva.“ DEDINSKÝ, M. M. Na úspech málo pestrosti. In Pravda, roč. 49, č. 331, s. 2, 9. 12. 1968 .

33 POLÁK, M. Viktor alebo „,čierny humor“. In Pravda, roč. 50, č. 83, s. 5, 9. 4.1969.
} 


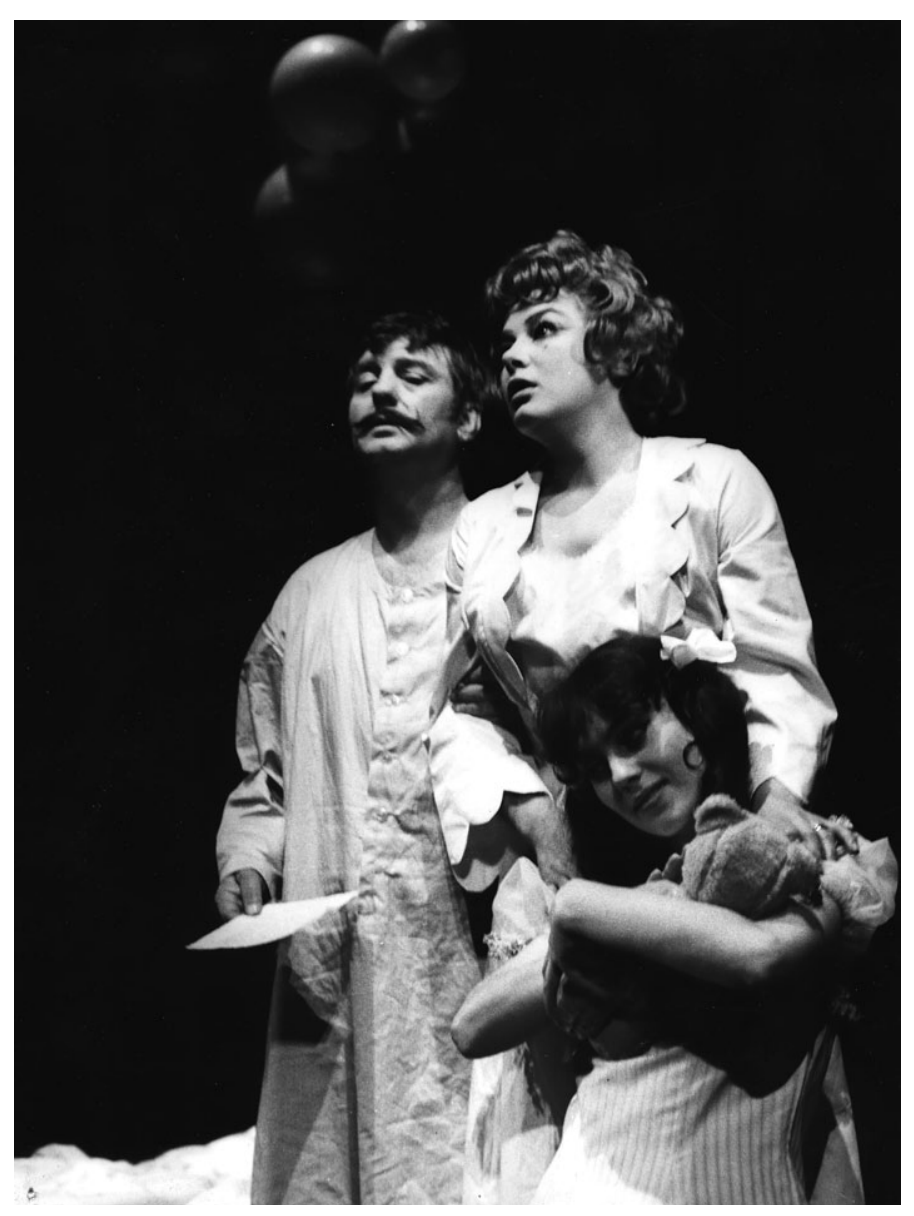

Roger Vitrac: Victor alebo vláda detí. Slovenské národné divadlo, premiéra 30. 3. 1969. Réžia Peter Mikulík. Július Pántik (Charles Paumelle), Elena Zvaríková Pappová (Thérése Magneauová), Soňa Valentová (Esther). Foto archív SND. Snímka Jozef Vavro.

gýň však tento predpoklad nepotvrdzuje. Medzi rokmi 1969 - 1974 stvárnila v SND iba devät postáv, pričom v inscenáciách Všetko v záhrade (7. 2. 1970), Žobrácke dobrodružstvo (31. 10. 1970) a Zurabája alebo Epitaf pre živého (18. 4. 1973) išlo síce o roly pre príbeh podstatné, ale z hl'adiska hereckého zástoja druhoradé, vzdialené vd’ačným charakterovým úlohám, ktorými ešte pred pár rokmi ohurovala martinské publikum. $^{34}$

Ak sa so Zvaríkovej Pappovej bratislavskou kariérou spája nejaká emblémová kreácia, tak to nebola Ruth ani Thérése, ale Marika Mondoková z Bukovčanovej drámy Kým kohút nezaspieva (30. 8. 1969). Opät išlo o postavu zo spoločenskej periférie, o ženu, ktorej erotické vyžarovanie nie je samočinnou osobnostnou črtou, ale profesijnou výhodou: bola totiž predstavitel'kou najstaršieho remesla. Autor v hre odohrávajúcej sa po potlačení Slovenského národného povstania v opustenej pivnici predostrel sociologicky pestrú vzorku slovenského národa: intelektuála Tomka, malomeštiačku

${ }^{34}$ Do výpočtu nezarad’ujeme epizódnu postavu Ženy, ktorú dodatočne doštudovala v inscenácii Rozkošný paroháč (premiéra 2. 4. 1972, rolu hrávala od 30. 12. 1972). 
Lekárnikovú, tajomného Tuláka, nevinných študentov Ondreja a Fanku netušiacich ešte o reálnych nástrahách života, ordinárnu babicu Babjakovú a i. Do tejto rôznorodej spoločnosti prichádza bezprostredná prostitútka Marika.

Zvaríkovej Pappovej vrcholnú bratislavskú kreáciu si môžeme aj dnes priblížit na základe televízneho filmu z roku 1972, s totožným hereckým obsadením a v totožnej réžii Jozefa Palku. Aj ked’ vezmeme do úvahy prenos do iného média (najmä hranie v časovo-priestorovom strihu), môžeme predpokladat', že herecké interpretácie sa v základných obrysoch nelíšili od ich javiskových originálov. Zvaríkovej Pappovej Marika od príchodu do chladnej pivnice nenechala diváka na pochybách o tom, aká žena vstúpila. Pozornost’ totiž nevenovala deviatim spoluväzňom, ktorí s napätím sledovali, koho d’alšieho priviedli nemeckí vojaci do ich provizórnej väzby, ale sa zamerala výhradne na svoj vzhl'ad. Upravovala si vlasy, snažila sa vyrovnat pokrčené oblečenie a až následne vykročila do priestoru ladnou, dráždivou chôdzou charizmatickej ženy. Ani ked' si uvedomila závažnost’ situácie, neprepadla panike, na nastolenej situácii sa skôr zabávala. K ironickému tónu, prezentovanému prostredníctvom suchého, akoby až hrdzou škrípajúceho hlasu, ju povzbudzovalo i to, že všetci boli konšternovaní nielen zo zatknutia a čakania na neznámo, ale i z prítomnosti jej samotnej - vulgárnej ženy, ktorá si nenechá nanútit’ servilnú pózu. Napätú atmosféru zl’ahčovala poznámkami vyslovenými s maximálnym osobným nadhl'adom. Ako u Mariky v texte, tak aj u jej hereckej predstavitel'ky vyhrávala vecnost' nad emočnostou. No to bol len počiatočný dojem. Zvaríkovej Pappovej Marika bola dobrou herečkou. Vedela, že nemôže ukázat’ skutočnú tvár neštastnej a životom ubitej ženy, ktorá má rovnakú hrôzu zo smrti ako zvyšných devät rukojemníkov. Nestretla by sa u nich s pochopením, ked’že ju považovali za menejcennú obyvatel'ku ich počestného mestečka. Až ked' ju obvinili z posluhovania nemeckým vojakom, vytrysklo z nej úprimné zúfalstvo, bezbrannost' i urazená l'udská hrdost'. Tento klúčový moment tlmočila herečka cez kŕčovité zovretie tela a syčivý tón hlasu, čerpajúci z posledných síl inak živelného naturelu postavy. Poukazovala tak na to, že jej Marika znesie opovrhovanie a urážky, ale len dovtedy, kým nezasiahnu jej ludský étos. Inak to bola triezva komentátorka, ktorá sa nebála ostrovtipnými poznámkami pointovat či kontrovat hádkam spoluväzňov utápajúcich sa v smrtel’nom zovretí pred možnou popravou. Kým z frizéra Uhríka či zverolekára Šusteka robil boj o holý život hysterických oportunistov schopných popriet’ v sebe všetky mravné zábrany, herečka v intenciách autora prezentovala Mariku ako ženu, ktorá si aj v extrémnej krízovej situácii zachováva čistotu morálnych princípov a ktorá „napriek svojmu čudnému spoločenskému postaveniu zostáva verná pravde a s akousi priamostou a samozrejmostou bráni zásady l’udského spolunažívania“" ${ }^{\prime 35}$. Vetu po Tulákovej smrti („Bol skutočný chlap, jediný chlap medzi nami“) vyslovila ako všeobecné konštatovanie, ako memento, ktoré takýmto odosobneným spôsobom zvolenej intonácie dokázalo prudko zasiahnut’ svedomie ostatných postáv. Milan Polák výstižne poznamenal: „Ale aj tu sa ukázal formát jednotlivých hercov a ked’ na prvom mieste spomínam predstavitel'ku prostitútky Mariky Elenu Pappovú-Zvaríkovú, tak predovšetkým preto, lebo táto herečka na ozaj obmedzenej ploche vyčarila na javisku malý herecký zázrak. Dokázala predovšetkým škálou svojho fyzického prejavu vyjadrit’ jemnými a presne

${ }^{35}$ ŠTEFKO, V. Človek na prahu smrti. In Smena, roč. 22, č. 216, s. 4, 13. 9. 1969. 


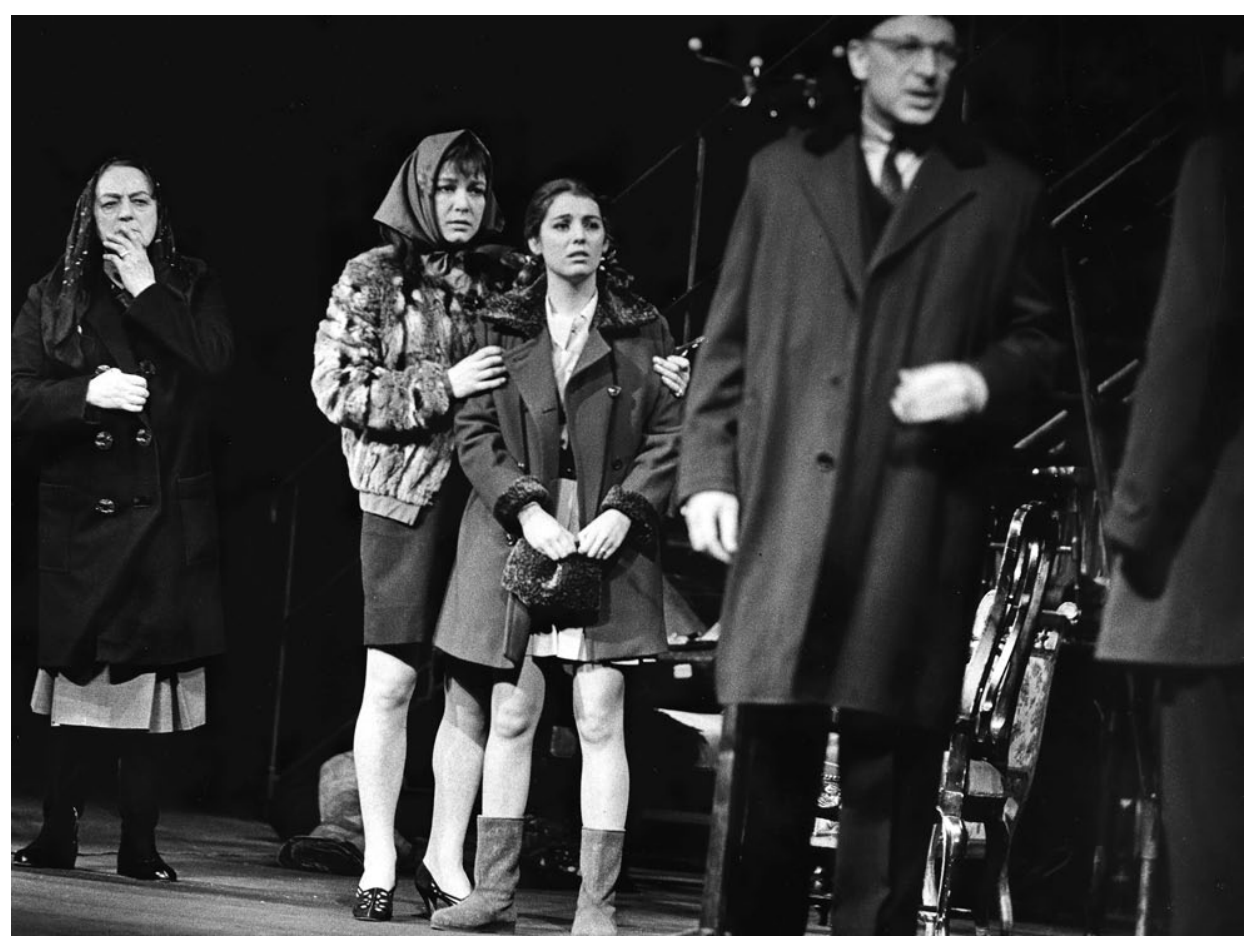

Ivan Bukovčan: Kým kohút nezaspieva. Slovenské národné divadlo, premiéra 30. 8. 1969. Réžia Jozef Palka. Hana Meličková (Babjaková), Elena Zvaríková Pappová (Marika Mondoková), Božidara Turzonovová (Fanka), Ladislav Chudík (Tomko). Foto Institut umění - Divadelní ústav Praha. Snímka Vilém Sochůrek.

volenými charakteristikami typ i jeho vnútorné rozpätie. Vyslovované repliky boli už iba dôsledkom jej fyzického prejavu držania tela, chôdze, gesta. “36

Onedlho nato čakalo Elenu Zvaríkovú Pappovú prvé divadelné stretnutie s Pavlom Hasprom, tvorcom poetiky vybičovanej dramatickosti, prudkej expresívnosti, analytických prienikov do beštiálnych sfér človeka, kde bezohl'adná emočnost’ nekompromisne vyhráva nad triezvym ráciom. Herečka s režisérom našli vzácnu umeleckú synergiu. Ich prvou spoločnou inscenáciou bola komorná psychologická hra Uga Bettiho Zločin na ostrove kôz (18. 10. 1969), dráma o troch osamelých ženách, ktorým do života nečakane vstúpi charizmatický Angelo a prebudí v nich zmysly, ktoré už pred rokmi samy umŕtvili. Kým matka Agata a jej dcéra Sylvia prijímali príchod cudzinca s dešpektom a obavami, tak impulzívna švagriná Pia okamžite vycítila príležitost' uspokojit svoju žiadostivost': „Zvaríkovej Pia je stelesnenie sexu, sexuálnej agresivity a túžby. Na javisku priam vidiet’ a cítit', ako ju Angelova prítomnost' rozpal'uje, ako postupne mení svoj vzt’ah k nemu i to, ako sa zmieruje s tým, že nie je jediná.“37 Teda aj Haspra v Zvaríkovej Pappovej vycítil vzácnu schopnost’ pre

${ }^{36}$ POLÁK, M. Človek v stave ohrozenia. In Pravda, roč. 50, č. 208, s. 5, 4. 9. 1969.

${ }^{37}$ ŠTEFKO, V. Vykol'ajený život. In Smena, roč. 22, č. 268, s. 4, 13. 11. 1969. 
interpretáciu zúfalých antihrdiniek, ktorých vonkajšková lascívnost’ je len mimikry ukrývajúce rozpoltenost’ doráňanej bytosti. Ako napísal Zoltán Rampák: „Hoci táto rola je v Bettiho dráme spomedzi všetkých ženských najženskejšia (lebo Pia pocituje od samého začiatku až do konca najmenej zábran vo svojom vztłahu k Angelovi), predsa nemožno povedat', že by Pappová-Zvaríková bola bezozvyšku podl’ahla svojmu - a možno, že len zdanlivému - hereckému naturelu, ktorého dominantou a zase možno iba zdanlivou - je dravá ženskost́. Najmä na začiatku, ked’ sa Pia stretla s Angelom, zazneli vo výkone Pappovej-Zvaríkovej tóny plachosti, ktorých výsledné pôsobenie bolo lyrizujúce, zl’udštovali pohl'ad na postavu, poetizovali dramatickú atmosféru a pôsobili ako účinný kontrast $\mathrm{k}$ d’alšiemu rozvoju postavy. " ${ }^{38}$ No popri uznanlivých kritických reflexiách sa stretávame aj s prvými polemikami o hereckej koncentrácii umelkyne: „Akoby sa táto herečka po sl’ubnom začiatku v novom súbore nevedela náležite aklimatizovat', jej herecký prejav je privel'mi a príliš viditelne a citel’ne postavený na vonkajškových znakoch, pôsobivý síce, ale nezvnútornený. “39 Nasledujúce roky ukázali, že to nebola posledná výčitka tohto druhu.

Po príchode Zvaríkovej Pappovej do Bratislavy stúpol o ňu záujem ako o televíznu a filmovú herečku ${ }^{40}$, predstavitel'ku predovšetkým všedných žien prenasledovaných životným stihomamom. V réžii Štefana Uhra bola submisívnou a voči diabolskej protivníčke bezbrannou Marianou Tobiášovou v Géniovi (1969) i vojnou sužovanou sedliačkou Irenou Krnáčovou vo Vel'kej noci a vel'kom dni (1974), pod vedením Petra Solana živelnou hotelovou komornou Zuzkou v Pán si neželal nič (1970), v Neveste hôl' (1971) Martina Ťapáka zase vytvorila postavu ordinárnej Mlynárky. Ak $\mathrm{v}$ divadle málokedy stvárňovala úlohy $\mathrm{v}$ klasickom repertoári, tak $\mathrm{v}$ televízii to bolo skôr naopak. No vd’aka hereckej nenútenosti neboli ani tu jej výkony portrétmi žien dávnych vekov, ale napriek historickým kostýmom priamymi odrazmi prejavu diváčok sediacich pred obrazovkami. Napríklad v réžii L'ubomíra Vajdičku vytvorila dve postavy zo sedliackeho prostredia (v jej divadelnom súpise takmer nevídaného): manipulatívnu Maru v Závejoch (1972) od VHV a koristnícku Katu Jahodovú v Tajovského Novom živote (1973). Príznačnejšie pre jej herecké uspôsobenie však boli tri roly osudových a pre okolie nebezpečne podmanivých hrdiniek svetovej spisby - Ibsenova Hedda Gablerová (1969), kde interpretka kládla dôraz na neovládatelnú neurotickost’ a stálu nespokojnost’ charizmatickej nihilistky; neštastne vydatá Jelena v Čechovovom Ujovi Váňovi (1970), ktorá nedokáže niest’ tarchu svojho údelu a v neustriehnutých gestických záchvevoch i tóne hlasu cítit jej túžbu vytrhnút’ sa zo stereotypu života; a najmä Lady Milfordová v Schillerových Úkladoch a láske (1971), dvorská kurtizána, ale - ako vývoj príbehu ukáže - aj osoba so vzácne vyvinutým zmyslom pre spravodlivost’ a sklonom k búrlivej citovej sebareflexii.

Naproti tomu, v divadelnej kariére Eleny Zvaríkovej Pappovej dochádza v tomto čase $\mathrm{k}$ prudkému ustrnutiu. Herečka sa nedostávala $\mathrm{k}$ tvárnejším dramatickým úlohám, a ak sa tak aj stalo, už ich nedokázala premenit’ na vierohodné výkony. Akoby strácala pôdu pod nohami, v jej herectve začali parazitovat’ dekoncentrácia a zovšeobecnenie. Úspešne nedopadlo ani jej hostovanie v Divadle na korze, kde v Kopitovej

\footnotetext{
${ }^{38}$ RAMPÁK, Z. Divadlo dravej človečiny. In Film a divadlo, 1969, roč. 13, č. 25, s. 25.

${ }^{39}$ RAPOŠ, G. Zločin na ostrove kôz. In Práca, roč. 24, č. 253, s. 6, 28. 10. 1969.

${ }^{40} \mathrm{Už}$ pred prestupom z Martina obsahoval jej súpis úloh približne tucet televíznych a filmových výkonov.
} 
groteske Ach, ocko, chudák ocko, mama t’a zavesila do skrine a ja som z toho strašne smutný (28. 3. 1970) stvárnila rolu Madame Rosepettlovej. Režisér Vladimír Strnisko totiž jednostrunne podčiarkol sexuálne podtexty hereckých kreácií, čím interpretom neumožnil vytvorit bohatšie profilované postavy. Podobne sa nevydaril Hasprov inscenačný pokus o Dürrenmattovu komickú parabolu Král Ján (27. 6. 1970), kde stvárnila temperamentnú bojovníčku proti král'ovskej nespravodlivosti Konstanciu.

Ak sa v tomto období dostala k podnetnej hereckej príležitosti, tak to bola Žena v Bukovčanovej komornej komédii Slučka pre dvoch alebo Domáca šibenica (20. 2. 1971) v réžii Jozefa Palku. Dominantná manželka držiaca svoju mužskú polovičku dlhé roky v domácom väzení priniesla Zvaríkovej Pappovej šancu znova preukázat’ umelecké kvality. Jej vlohy pre ženy furiózneho temperamentu ukrývajúce vlastnú slabost’ pod pláštikom nadradenosti, aj jej cit pre jemne groteskný nadhl'ad z nej robili vhodnú kandidátku na presvedčivé stvárnenie tejto úlohy. V inscenácii dokonca hrala pár so svojím pravidelným divadelným, televíznym i filmovým partnerom Jozefom Kronerom, s ktorým už neraz vytvorila fyzicky zretel’ný a tým herecky produktívny kontrast (útly, no výrazovo exponovaný Kroner verzus robustná, ale prejavom komótnejšia Zvaríková Pappová). Tentoraz však jej výkon poznačila strnulost’ a slabé preniknutie do atmosféry inscenácie. Gabriel Rapoš konštatoval: „E. Zvaríková vytvára snaživo a úzkostlivo d’alšiu zo série postáv, k akým sa v činohre SND dostáva, ale nie je to načretie do rezerv jej talentu, znaky monotónnosti, hrania pre hranie, neúnavného zápasu o priestor a pozornost' diváka a často iná vol'ba hereckých prostriedkov ako u jej partnerov, zatlačili jej výkon do úzadia." ${ }^{\prime 4}$

Poslednou úlohou Eleny Zvaríkovej Pappovej pred jej predčasným úmrtím bola Genoveva v Casonovej alúzii na magický realizmus Dom so siedmimi balkónmi (16. 6. 1973). Oproti predošlým postávam išlo o ústrednú rolu. Zároveň po prvýkrát na javisku SND dostala možnost' nehrat’ padlého anjela, rafinovanú plebejku či autokratickú matrónu. Režisér Pavol Haspra, ktorý stále dôveroval herečkiným dispozíciám, zaexperimentoval a ponúkol jej úlohu v absolútnom opozite vymenovaných prívlastkov. Genoveva je totiž postava lyrického založenia, jemnocitná, traumatizovaná žena uzavretá vo vlastnom iluzórnom svete, ktorému jej pragmatické a na zisk zamerané okolie nedokáže porozumiet'. Júnovú premiéru i prvé reprízy však odohrala alternujúca Viera Strnisková, Elena Zvaríková Pappová začala postavu senzitívnej hrdinky zo španielskych hôr hrávat’ až v nasledujúcej divadelnej sezóne. V dôsledku toho sa na jej interpretáciu, ktorá musela už len na základe rozdielnej umeleckej letory oboch herečiek vyznievat’ výrazne odlišne, nezachovala kritická reflexia. Iba krátka informácia od Gabriela Rapoša: „A už tu sme sa presvedčili o tom, ako možno vybudovat tú istú postavu, v tej istej réžii trocha inak, v iných polohách, z iného aspektu hereckého naturelu, so zvýrazňovaním iných polôh, diferenciáciou vnútorného zápasu - a predsa v spoločnom výsledku. “42 Hodnotiace stanovisko i bližšia charakterizácia, ktoré by priblížili odchýlky hereckého výkladu, však absentujú. Rovnako ako absentovali d’alšie divadelné príležitosti pre herečku. Zvyšok sezóny 1973/1974 už len dohrávala staršie úlohy, nové neprichádzali. Niekdajšia protagonistka martinského súboru a výnimočná predstavitel'ka tragickej modernej ženy sa lúčila s javiskom v tichosti, bez vzrušujúcich vibrátov, ktorými oslňovali jej femmes

\footnotetext{
${ }^{41}$ RAPOŠ, G. Bukovčan na Malej scéne SND. In Práca, roč. 26, č. 45, s. 6, 23. 2. 1971.

${ }^{42}$ (gr). [Gabriel Rapoš]. Alternácie. In Film a divadlo, 1973, roč. 17, č. 25, s. 14.
} 
Alejandro Casona: Dom so siedmimi balkónmi. Slovenské národné divadlo, premiéra 16. 6. 1973. Réžia Pavol Haspra. Elena Zvaríková Pappová (Genoveva). Foto archív SND. Snímka Jozef Vavro.

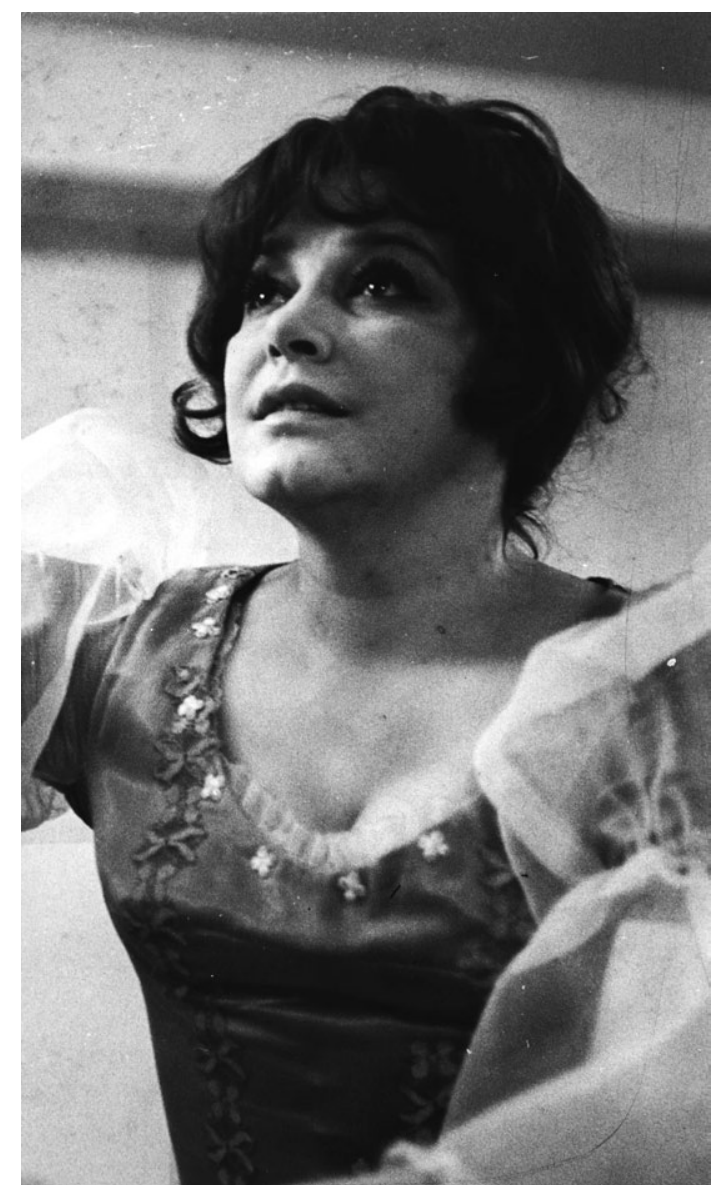

fatales Máša, Vasilisa či Marika - kreácie, ktoré aj po rokoch ostávajú zapísané do novodobých dejín slovenského herectva.

\section{ELENA ZVARÍKOVÁ PAPPOVÁ. FEMME FATALE OF SLOVAK ACTING}

\section{Karol MIŠOVIC}

Elena Zvaríková Pappová (1935 - 1974) was one of the most distinctive phenomenon's among Slovak actors in the second half of the 20th century, but to this day her artistic profile has not been comprehensively researched. The most interesting period of her career was associated with her engagement at the Theatre of the Slovak National Uprising in Martin (1954 - 1968). To begin with she played marginal characters and genre figures, but from the late fifties she gradually became one of the leading protagonists' of the ensemble. She mastered coping with stage stylization, but she 
felt at her best in civilian theatre poetics. In which she found a suitable medium for the believable portrayal of her character's internal conflicts and contemplation for the drama of the characters she played. She was typecast in roles of plebeian, dominant and unrestrained women. Her corpulent appearance combined with her individual sense of humour was regularly used by directors in the comedy repertoire. Yet she also became a sought-after representative of fateful women who brought sexual irritation and fierce animality to the stage. The subsequent transition to the drama of the Slovak National Theatre in 1969 meant a sharp drop in her acting opportunities.

\section{LITERATÚRA}

DEDINSKÝ, Móric Mittelmann. Na úspech málo pestrosti. In Pravda, roč. 49, č. 331, s. 2, 9. 12. 1968.

FUCHS, Aleš. Kdo zabloudil? In Divadelní noviny, roč. 3, č. 13, s. 5, 20. 1. 1960.

GALANDOVÁ, Eva. Tri sestry v Divadle SNP. In Smena, roč. 20, č. 22, s. 4, 26. 1. 1967.

kol. Encyklopédia dramatických umení Slovenska II : M - Ž. Bratislava : Veda, 1990. ISBN 80-2240001-7.

LEHUTA, Emil. Zo zápisníka Emila Lehutu. In Slovenské pohlady, 1968, roč. 84, č. 3, s. 149.

MELIŠOVÁ, Blanka. „Volpone“ v Armádnom divadle. In Ciel', 6. 4. 1957.

MICHAELLI, Daňo [Daniel]. Čepurinove „Jarné vody“ v Armádnom divadle. Neidentifikovaný výstrižok článku.

MRLIAN, Rudolf. „Irkutský príbeh“ v Martine. In Pravda, roč. 43, č. 358, s. 3, 29. 12. 1962.

POLÁK, Milan. Človek v stave ohrozenia. In Pravda, roč. 50, č. 208, s. 5, 4. 9. 1969.

POLÁK, Milan. Sartre na javisku. In Film a divadlo, 1962, roč. 6, č. 12, s. 13.

POLÁK, Milan. Viktor alebo „čierny humor“. In Pravda, roč. 50, č. 83, s. 5, 9. 4. 1969.

PORUBJAK, Martin. Williams v Martine. In Kultúrny život, roč. 23, č. 22, s. 5, 31. 5. 1968.

R. Odišla hrdinka Čechovových hier. In Film a divadlo, 1974, roč. 18 , č. 20 , s. 15.

RAMPÁK, Zoltán. Divadlo dravej človečiny. In Film a divadlo, 1969, roč. 13, č. 25, s. 25.

RAMPÁK, Zoltán. Nič nového u nás s Pinterom. In Film a divadlo, 1969, roč. 13, č. 2, s. 24.

RAPOŠ, Gabriel. Bukovčan na Malej scéne SND. In Práca, roč. 26, č. 45, s. 6, 23. 2. 1971.

RAPOŠ, Gabriel. Zločin na ostrove kôz. In Práca, roč. 24, č. 253, s. 6, 28. 10. 1969.

ŠTEFKO, Vladimír. Človek na prahu smrti. In Smena, roč. 22, č. 216, s. 4, 13. 9. 1969.

ŠTEFKO, Vladimír. Divadlo, ktoré vzniklo : štyridsat' rokov divadla SNP v Martine. Martin : Osveta, 1984. $281 \mathrm{~s}$.

ŠTEFKO, Vladimír. Divadlo ironie a relativity. In Divadlo, 1969, č. 2, s. 77.

ŠTEFKO, Vladimír. Vykolajený život. In Smena, roč. 22, č. 268, s. 4, 13. 11. 1969.

ŠUGÁR, Štefan. O outsideroch spoločnosti. In Kultúrny život, roč. 22, č. 30, s. 9, 28. 8. 1967.

ŠUGÁR, Štefan. Priemernost' je nesmrtel'ná aj v divadle. In Pravda, 11. 3. 1966, roč. 47, č. 69, s. 2.

VÁH, Juraj. Len výborná titulná postava. In Film a divadlo, 1965, roč. 9, č. 15, s. 14.

VRBKA, Stanislav. Elena Zvaríková - od mladosti pani herečka. In Listy SND, propagačný dvojmesačník, 1989 - 1990, č. 5, s. 8.

Karol Mišovic

Ústav divadelnej a filmovej vedy CVU SAV

Dúbravská cesta 9

84101 Bratislava

e-mail: karol.misovic@savba.sk 